\title{
ANÁLISE DO PROTEOMA DO FLUÍDO INTERCELULAR DE FOLHAS DE LARANJEIRAS INFECTADAS COM Xylella fastidiosa
}

\section{BEATRIZ SILVEIRA VIANA DE ALMEIDA}

Dissertação apresentada à Escola Superior de Agricultura "Luiz de Queiroz", da Universidade de São Paulo, para obtenção do título de Mestre em Agronomia, Área de Concentração: Microbiologia Agrícola.

PIRACICABA

Estado de São Paulo - Brasil

Novembro - 2001 


\title{
ANÁLISE DO PROTEOMA DO FLUÍDO INTERCELULAR DE FOLHAS DE LARANJEIRAS INFECTADAS COM Xylella fastidiosa
}

\author{
BEATRIZ SILVEIRA VIANA DE ALMEIDA \\ Bacharel em Ciências
}

Orientador: Prof.Dr. MARCIO RODRIGUES LAMBAIS

Dissertação apresentada à Escola Superior de Agricultura "Luiz de Queiroz", da Universidade de São Paulo, para obtenção do título de Mestre em Agronomia, Área de Concentração: Microbiologia Agrícola.

PIRACICABA

Estado de São Paulo - Brasil

Novembro - 2001 
Dados Internacionais de Catalogação na Publicação (CIP) DIVISÃO DE BIBLIOTECA E DOCUMENTAÇÃO - ESALQ/USP

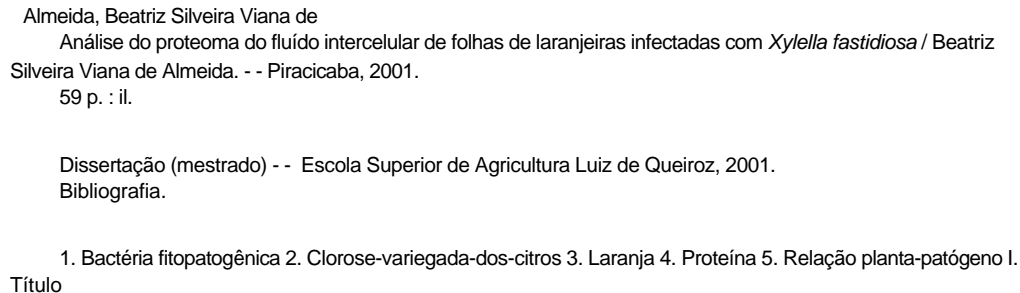

CDD 634.31

"Permitida a cópia total ou parcial deste documento, desde que citada a fonte - $\mathrm{O}$ autor" 
Aos meus pais,

Tarcísio e Lícia

OFEREÇO

À minha filha Julia

DEDICO 


\section{AGRADECIMENTOS}

Ao orientador Prof. Dr. Marcio Rodrigues Lambais, mentor intelectual desse trabalho, por ter me dado a oportunidade de executar esse projeto.

À FAPESP, orgão financiador desse trabalho.

Aos meus queridos colegas de laboratório e de tantas horas, Leandra, Elizabeth, Adriana, Adrianinha, Denise, Daniele, Ângela, Simão, Juliano, lara, Vinícius, Renato, Taís, Robison, Wiston pela harmoniosa convivência.

À Cláudia M. Bellato, pelas dicas da eletroforese bidimensional.

Aos técnicos Denise e Fernando.

Aos funcionários do departamento de solos e nutrição de plantas pela cordialidade.

À funcionária Martinha, pelos diversos cafés que me forneceu.

Ao Marco Nogueira por ter sido solícido em todas as horas.

À Lúcia Hoffmann, Giuliana e Maria Isabel pelas conversas técnicas e não técnicas.

Ao Rogério de Costa Campos pela amizade e por ter sido um companheiro indispensável nas coletas de Matão.

Aos funcionários da Fazenda Cambuhy, pela atenção e colaboração na coleta das amostras.

Aos Professores Sérgio Pascolati (Departamento de Fitopatologia) e Marli Fiore (CENA) pelas sugestões no exame de qualificação.

Ao Laboratório de química de proteínas (LAQUIP-UNICAMP) por ter dado o espaço para realizar parte do meu trabalho. 
Ao Marcus Bustamante Smolka, profissionalmente pelas preciosas sugestões e informações técnicas no meu trabalho, e pessoalmente por tudo que representa.

À minha Filha Julia que nasceu no meu primeiro ano de Mestrado, pela compreensão da minha ausência em algumas horas.

Ao pai de minha filha, Paulo Ernesto Vergamini Luna pela amizade e o constante incentivo para minhas pesquisas.

Aos meus pais Tarcísio e Lícia por me dado a vida e todos os seus acessórios.

À minha segunda mãe Amazildes Moreira da Silva e seu filho pela constante dedicação.

À minha irmã Maria Fernanda pela amizade.

À velha amiga de todas as horas Maria Paula B. Orlando. 


\section{SUMÁRIO}

Página

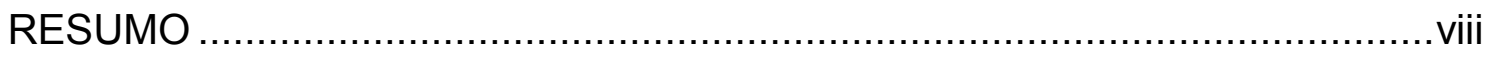

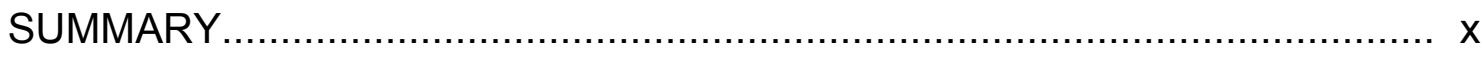

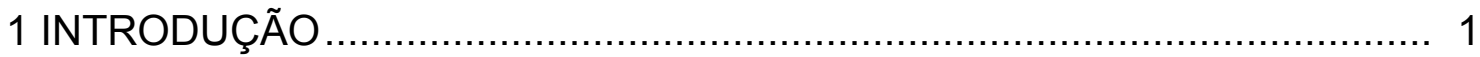

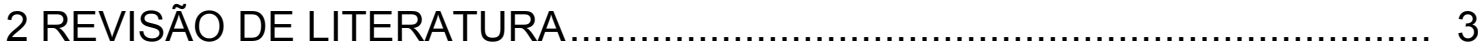

2.1 A clorose variegada dos Citros e a Xylella fastidiosa ................................. 3

2.2 Regulação das interações planta-patógeno.......................................... 7

2.3 Análise do proteoma para o entendimento de interações planta-

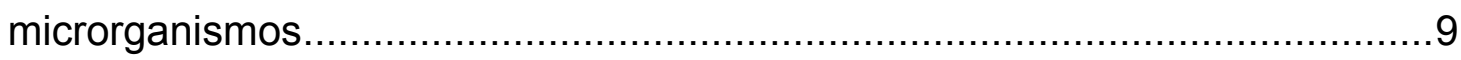

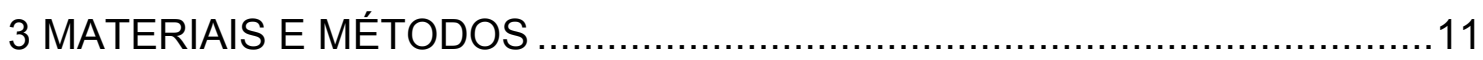

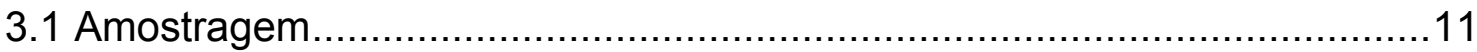

3.1.1 Experimento 1: Análise de variabilidade dos proteomas de fluído intercelular de folhas de laranjeira de diferentes localidades..........................11

3.1.2 Experimento 2: Caracterização de proteínas do fluído intercelular de

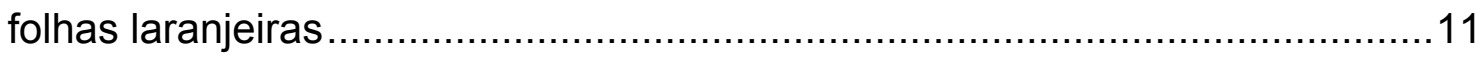

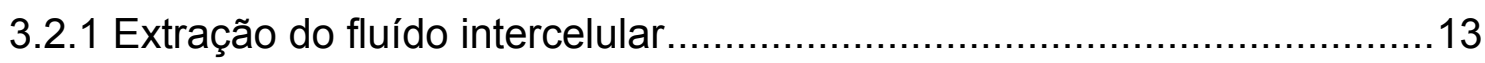

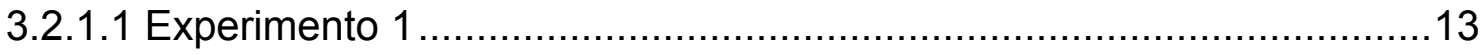

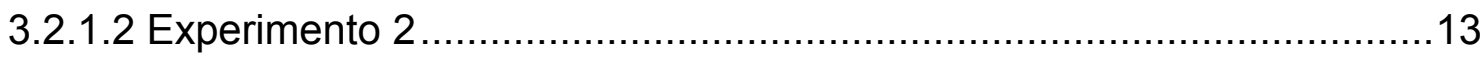

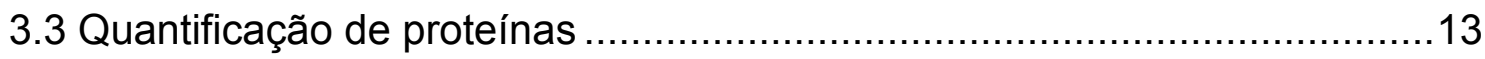

3.4 Determinação de contaminação citoplasmática.......................................13

3.5 Confirmação da presença ou ausência do patógeno.................................15

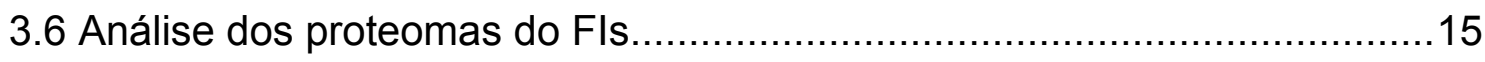

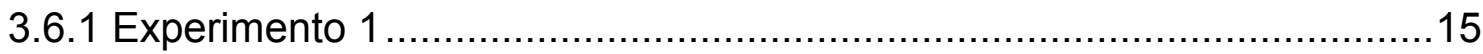

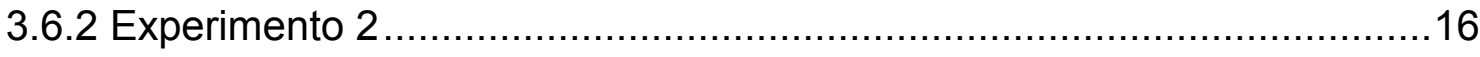




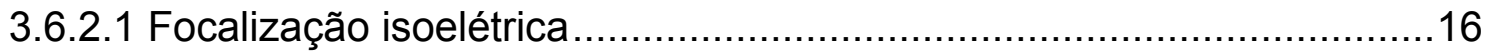

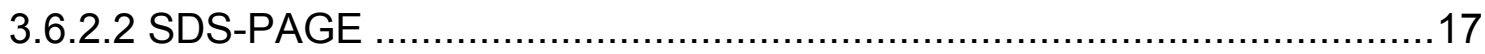

3.6.2.3 Coloração das proteínas por impregnação com prata ........................17

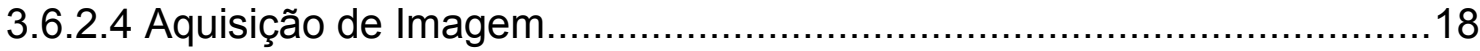

3.6.2.5 Transferência das proteínas para membrana, seqüenciamento da extremidade $\mathrm{N}$-terminal e análise dos aminoácidos....................................18

3.6.2.6 Digestão das proteínas com tripsina e preparação para espectometria

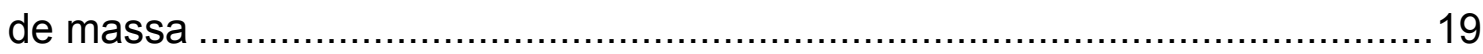

3.6.2.7 Separação dos peptídeos das isoformas utilizando cromatografia líquida

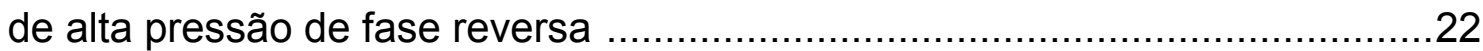

3.6.2.8 Seqüenciamento dos peptídeos interno isoformas ...........................22

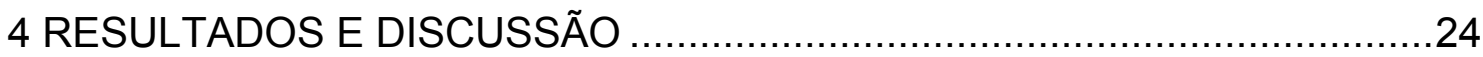

4.1 Determinação de contaminação citoplasmática......................................24

4.2 Confirmação da presença ou ausência do patógeno..................................24

4.3 Análise da variabilidade dos proteomas do $\mathrm{FI}$ de folhas de laranjeiras de

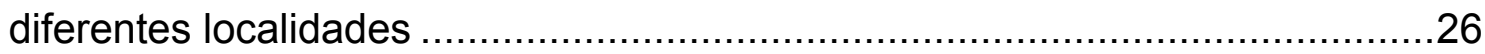

4.4 Caracterização das proteínas do FI pela eletroforese bidimensional...........31

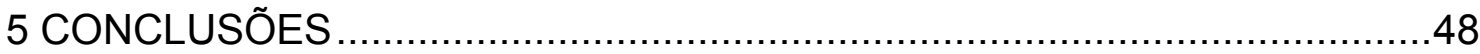

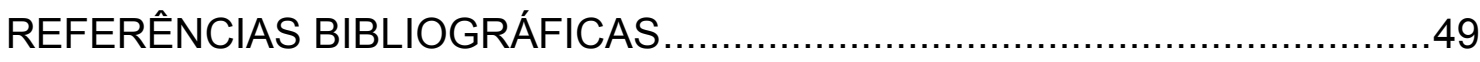




\title{
ANÁLISE DO PROTEOMA DO FLUÍDO INTERCELULAR DE FOLHAS DE LARANJEIRAS INFECTADAS COM Xylella fastidiosa
}

\author{
Autora: BEATRIZ SILVEIRA VIANA DE ALMEIDA \\ Orientador: Prof. Dr. MARCIO RODRIGUES LAMBAIS
}

\section{RESUMO}

Com o objetivo de compreender os mecanismos que regulam a interação citros-Xf procurou-se identificar e caracterizar proteínas com acúmulo diferencial no apoplasto de folhas de Citrus sinensis var. Pêra infectadas com Xf, apresentando ou não sintomas de CVC, através de eletroforese bidimensional em géis de poliacrilamida desnaturante e espectrometria de massa (MALDI-ToF). O fluído intercelular (FI) foi extraído de folhas de laranjeira cultivadas em campos experimentais. A presença ou ausência do patógeno foi confirmada por amplificação, através de PCR, de fragmentos específicos de DNA da bactéria a partir de DNA total extraído do pecíolo da folha. Para avaliar a complexidade dos proteomas, e a sua variabilidade entre plantas de diferentes localidades, as proteínas foram separadas por eletroforese em géis de poliacrilamida desnaturantes. Os resultados indicam que o proteoma do $\mathrm{FI}$ de plantas de localidades diferentes são distintos, independente da presença de $\mathrm{Xf}$ e ou sintomas de CVC, e também independe do local onde as amostras foram coletadas. Para a identificação de proteínas com acúmulo diferencial no $\mathrm{FI}$, quantidades iguais de proteínas do FI de folhas dos diferentes tratamentos foram separadas por eletroforese bidimensional em gel de poliacrilamida 
desnaturante. Proteínas foram com acúmulo diferencial selecionadas para o seqüenciamento da extremidade $\mathrm{N}$-terminal. As proteínas mais abundantes e com aúmulo diferencial nas condições experimentais possuem massa molecular aparente de $41 \mathrm{kDa}$ e pl variando de 4,1 a 5,5. Algumas proteínas de $\mathrm{Fl}$ de folhas infectadas sem sintomas de CVC, massa molecular de $41 \mathrm{kDa}$, pl 4,2 a 5 apresentaram aumento no acúmulo de proteínas variando de 89 a 129\% relação aos $\mathrm{Fl}$ de folhas de laranjeiras não-infectadas. Suas seqüências Nterminal, e os espectros de massa de seus peptídeos, após digestão com tripsina, são praticamente idênticos, indicando que elas são isoformas da mesma família de proteinas. As seqüências $\mathrm{N}$-terminal dessas proteínas ou dos peptídeos gerados por clivagem com tripsina não apresentam homologia com proteínas/genes nos bancos de dados públicos, sugerindo que essas proteínas são específicas do apoplasto de folhas de laranjeiras e podem ter papel importante na regulação da interação citros-Xf. 


\title{
ANALYSIS OF THE INTERCELLULAR FLUID PROTEOME OF XYLELLA FASTIDIOSA - INFECTED CITRUS LEAVES
}

\author{
Author: BEATRIZ SILVEIRA VIANA DE ALMEIDA \\ Adviser: MARCIO RODRIGUES LAMBAIS
}

\section{SUMMARY}

In order to understand the mechanisms regulating the Xylella fastidiosacitrus (Citrus sinensis var. Pêra) interaction, proteins with differential accumulation in the apoplast of Xf-infected citrus leaves with or without disease symptoms as compared to non-infected leaves, were identified and characterized using 2D-PAGE and mass spectrometry (MALDI-ToF). The intercellular fluid (IF) was extracted by infiltration and centrifugation from field grown leaves segments. The presence of $\mathrm{Xf}$ in the leaves was determined by PCR-amplification of specific DNA fragments. SDS-PAGE was performed in a discontinuous system using equal amounts of IF proteins from non-infected and infected leaves with or without CVC symptoms collected from field grow plants at diferrent locations. Protein profiles were compared using discriminant analyses, based on the relative abundance of each protein. The results indicated that the IF proteome of plants from different localities are distinct, independent of the presence of $\mathrm{Xf}$ and/or CVC symptoms. Also, independent of the local where the samples were collected, the IF proteome of non-infected leaves and symptomatic infected leaves were distinct. Using 2D-PAGE it was 
possible to identify proteins with differential accumulation in the IF of symptomatic and asymptomatic Xf infected citrus leaves, as compared to noninfected controls. The must abundant proteins in the IF showing differential accumulation have apparent molecular mass of $41 \mathrm{kDa}$ and $\mathrm{pl} 4,2-5$. The accumulation in the IF asymptomatic Xf infected citrus leaves were $89-129 \%$ higher than non-infected controls. Their N-terminal position and the mass spectra of their peptides, after trypsin digestion, are mostly identical, indicating that the are isoforms of the same proteins familiy. N-terminal sequences of the proteins and their internal peptides showed no homology to known genes/proteins in public database, suggesting that these proteins are apoplastic citros specifid proteins, and that they may have a important roles in regulating citrus-Xf interactions. 


\section{INTRODUÇÃO}

A clorose variegada dos citros (CVC) é causada pela bactéria gramnegativa restrita ao xilema Xylella fastidiosa (Xf) e vem sendo extensivamente pesquisada, pois trata-se de um dos maiores problemas da citricultura brasileira na atualidade.

O genoma da Xf já foi totalmente seqüenciado, mas os mecanismos que controlam o processo de infecção e o desenvolvimento de doenças ainda não foram desvendados. (Simpson et al., 2000)

Um sistema biológico complexo pode ser melhor compreendido através do estudo da expressão diferencial de genes específicos em duas populações de células, em condições ambientais/estágio de desenvolvimento específicos. A análise diferencial de proteomas tem sido usada como uma ferramenta de estudo da expressão gênica em interações plantamicrorganismos (Guttemberger \& Hampp, 1992; Guerreiro et al., 1996; Lambais, 1998). Normalmente, esses proteomas são extraídos de tecido vegetal infectado e analisado por eletroforese bidimensional em gel de poliacrilamida. Freqüentemente, os padrões de distribuição dessas proteínas são complexos, dificultando a identificação de proteínas importantes na regulação das associações planta-microrganismos.

Proteínas secretadas no apoplasto podem ter papéis importantes na regulação de interações patogênicas ou simbióticas, e a análise do proteoma do FI pode ser uma alternativa mais eficiente para identificar proteínas regulatórias importantes (Mukherjee et al.,1996; Lambais, 1998). Adicionalmente, como o número de proteínas no apoplasto é inferior ao número de proteínas em tecido vegetal infectado, seus padrões de separação por eletroforese bidimensional são mais simples, facilitando a identificação daquelas com acúmulo diferencial. 
Assim, a caracterização e identificação de proteínas no $\mathrm{FI}$ de folhas de laranjeiras com acúmulo induzido em plantas infectadas com Xf e sintomas de CVC, em relação a plantas não-infectadas ou infectadas assintomáticas poderá levar à identificação de fatores de patogenicidade/virulência essenciais para o desenvolvimento da doença, e contribuir para o seu controle definitivo.

Esse trabalho tem por objetivo comparar os proteomas do $\mathrm{Fl}$ de folhas de laranjeiras não-infectadas com $\mathrm{Xf}$, infectados com $\mathrm{Xf}$, mas sem sintomas de CVC e infectadas com Xf com sintomas de CVC, identificar e caracterizar parte das proteínas mais abundantes e com acúmulo diferencial nas diferentes condições. 


\section{REVISÃO DE LITERATURA}

\subsection{A Clorose Variegada dos Citros e a Xylella fastidiosa}

A clorose variegada dos citros (CVC) foi constatada pela primeira vez no Brasil em 1987, em pomares de Colina, São Paulo (Rossetti et al., 1990) e logo depois, no Triângulo Mineiro e nas regiões norte e noroeste do estado de São Paulo (De Negri, 1990). Em 1988, a CVC foi diagnosticada em Macaubal (SP), onde a doença mostrou-se bastante severa, rapidamente disseminandose por outras regiões do Estado (Tanabi, São José do Rio Preto, Mirassol, Cedral, Barretos, Bebedouro, Colina, Jaborandi, Matão), Triângulo Mineiro, e Alfenas (MG), alcançando a fronteira do Mato Grosso do Sul e arredores de Campinas (Tubelis, 1992a). Posteriormente, a CVC foi constatada no Rio de Janeiro (Lee et al., 1991a), Goiás (Tubelis et al.,1993), Paraná (Leite et al., 1993) e na Zona da Mata de Minas Gerais (Mizubuti et al., 1994). Mais tarde, foi detectado em Sergipe, Santa Catarina, Rio Grande do Sul e Distrito Federal (Tubelis, 1992b).

Os primeiros sintomas da CVC são observados nas folhas, passam posteriormente para os frutos e acabam afetando a planta toda. As plantas infectadas com Xf apresentam redução de crescimento, redução da emissão de brotações de primavera, morte de alguns galhos ponteiros, encurtamento de entrenós, surgimento de brotações basais vigorosas e com características juvenis (espinhos, folhas largas e caule angular) (Machado et al., 1992). As folhas apresentam-se amareladas, com área reduzida. Com o agravamento dos sintomas, as folhas mais velhas murcham e morrem. Manchas cloróticas são observadas na face adaxial do limbo, correspondendo a manchas de coloração ferrugínea na face abaxial, as quais foram sido descritas como "bolhas de goma" (Queiroz-Voltan \& Paradela Filho, 1999). Os sintomas nos frutos só se 
manifestam quando a doença está em fase avançada. Os principais sintomas nos frutos são: redução acentuada de tamanho, endurecimento da casca, amarelecimento precoce, desenvolvimento de vários frutos por galho $\mathrm{e}$ surgimento de lesões marrom-escuro (tipo queimadura) (Machado et al., 1992). Frutos com sintomas de CVC são inadequados para o comércio (Rossetti \& De Negri, 1990; Lee et al.,1991b).

O Estado de São Paulo e da Flórida (EUA) são as principais áreas citrícolas do mundo. São Paulo possui uma área de aproximadamente 630.000 ha com 164 milhões de árvores com uma produção anual de 374 milhões de caixas de laranja, correspondente a $87 \%$ da produção nacional e a $30 \%$ da mundial. A indústria cítrica brasileira emprega 400.000 funcionários, distribuídos em 204 cidades, e é abastecida por 20.000 produtores. Até 1996, os principais importadores de cítricos eram a União Européia (68,8\%), América do Norte (18,5\%) e Ásia (9,5\%).

A variedade mais suscetível à CVC é a Pêra com $38 \%$ de incidência da doença. A variedade Natal e Valência apresentam $26 \%$ e $17 \%$ de incidência de respectivamente. A estimativa geral de incidência de CVC em 1997 foi de 19,8\%, correspondendo a novos casos de contaminação. Hoje, aproximadamente, $30 \%$ das plantas cítricas de São Paulo estão infectadas com CVC. Isso corresponde aproximadamente a 60 milhões de plantas, e a um prejuízo de U\$ 300 milhões por ano (Fundecitrus, 2001).

A disfunção do xilema tem sido sugerida como a principal causa dos sintomas da CVC. Essa disfunção está relacionada com a oclusão dos vasos do xilema por "gomas", tiloses ou células de Xf (Hopkins, 1989). Não se sabe se tais oclusões seriam suficientes para causar todos os sintomas da doença. Há hipóteses alternativas associando os sintomas de CVC com fitotoxinas, possivelmente produzidos pela Xf (Lee et al., 1982) ou com desbalanço hormonal em plantas infectadas (French \& Stassi, 1978).

A transmissão da Xf ocorre através de cigarrinhas. Em anos chuvosos, elas aparecem na primavera e, em anos secos, surgem mais tarde, 
no verão. É provável que dessa sazonalidade seja a preferência das cigarrinhas por brotações jovens, as quais ocorrem com maior freqüência em épocas de chuva (Fundecitrus, 2001). As cigarrinhas mais importantes na transmissão de Xf são: Oncometopia facialis, Dilobopterus costalimai e Acrogonia sp. Além destas, mais sete espécies foram comprovadamente capazes de transmitir a Xf: Bucephalogonia xanthophis, Plesiommata corniculata, Sonesimia grossa, Homalodisca ignorata, Ferrariana trivittata, Macugonalia leucomelas, Parathona gratiosa ( Fundecitrus, 2001). As cigarrinhas sendo insetos sugadores do xilema de plantas, em plantas infectadas adquirem a Xf, e podem transmití-la para plantas sadias. Cigarrinhas adultas mantém a habilidade em transmitir a Xf durante toda a sua vida.

Uma das características da Xf é sua vasta gama de hospedeiros, incluindo em 28 famílias de monocotiledôneas e dicotiledôneas, e até 100 espécies diferentes (Viera, 1999). Dentre os hospedeiros da Xf estão a alfafa, videira, pessegueiro, amendoeira, ameixeira, cafeeiro e citros (Machado et al., 1992).

No Brasil, várias plantas invasoras que ocorrem naturalmente em pomares de citros foram identificadas como hospedeiras da Xf. Um exemplo disto é o capim-marmelada, capim-colchão, capim-quicuio, capim-estrada, poaia-branca, assa-peixe, apaga-fogo, braquiária, capim-carrapicho, capimamargoso, erva-de-Santa Luzia, erva-quente, maria-pretinha, picão e tapoeraba (Leite et al., 1997, Travensolo \& Leite, 1996). A presença de plantas hospedeiras em pomares de citros é bastante preocupante, já que elas são potenciais fontes de inóculo. Além disto, algumas destas plantas não apresentam os sintomas de doença (Viera, 1999), dificultando a identificação de plantas infectadas e, conseqüentemente, o controle da população do patógeno nos pomares infectados.

Os estudos de variabilidade genética entre isolados de Xf obtidos de diferentes hospedeiros suportam a hipótese de que essas bactérias constituem uma única espécie (Chen et al., 1992ab; Wells et al., 1987). No entanto, existe 
variabilidade genética suficiente para justificar a separação ao nível infrasubespecífico (Chen et al., 1992ab; Hopkins et al., 1989; Wells et al., 1987).

Todas as estirpes de $\mathrm{Xf}$ requerem meio complexos para crescimento, porém, podem ser separadas em dois grupos distintos, com base em sua nutrição (Davis et al., 1980, Hopkins, 1988, Kamper et al., 1985). O grupo do definhamento da vinca cresce nos meios PD3 (Davis et al., 1978), PW (Davis et al.,1981), BCYE (Wells et al., 1981) e CS-20 (Chang \& Schaad 1982); já, o grupo da redução do porte do pessegueiro cresce em PW, BCYE e CS-20, mas não em meio PD3.

A caracterização taxonômica e a identificação rápida de patovares de Xf são essenciais para pesquisas em ecologia, epidemiologia, e controle da doença (Hopkins, 1989). A confiabilidade dos testes de patogenicidade é questionável, pois as estirpes podem perder a virulência em meio de cultura (Hopkins, 1984). Testes serológicos com anticorpos policlonais, como difusão em gel, imunofluorescência e ELISA, não distinguem as estirpes de Xf na maioria dos casos (Davis et al., 1980, French \& Kitagima, 1978). No entanto, utilizando-se anticorpos monoclonais é possível distinguir diferentes estirpes de Xf (Davis et al., 1983). Da mesma forma, seqüências repetitivas de DNA, presentes no genoma de bactérias, têm sido utilizadas na caracterização de isolados em nível infraespecífico (Louws et al., 1995).

\subsection{Regulação de interações planta-patógeno}

A invasão dos tecidos vegetais por microrganismos patogênicos é regulada por várias características inerentes à planta ou por alterações bioquímicas durante o processo de infecção (Pascholati \& Leite, 1995). As interações planta-patógeno podem ser classificadas em incompatíveis ou compatíveis. As interações incompatíveis são caracterizadas pela ocorrência da resposta de hipersensibilidade $(\mathrm{RH})$, i.e acúmulo de compostos com atuação fungitóxica e/ou fungistática denominados fitoalexinas (Salunkhe \& 
Sharma, 1991) e morte celular, com conseqüente resistência à infecção. (Hayward \& Mariano, 1997).

A resistência do hospedeiro é caracterizada pela sua natureza dinâmica e coordenada, mostra-se como um sistema multicomponente, onde o nível de resistência resulta na somatória das contribuições individuais de diferentes mecanismos de resistência.

Os mecanismos fatores de resistência do hospedeiro podem ser divididos em duas categorias: pré-formados e pós-formados (Agrios, 1997; Isaac, 1992; Pascholati \& Leite, 1995). Os mecansimos pré-formados (passivos/constitutivos) englobam os mecanismos de defesa presentes nas plantas antes do contato do patógeno, e podem ser subdivididos em estruturais (cutícula, tricomas, estômatos, fibras/vasos condutores) e bioquímicos (fenóis, alcalóides glicosídios, lactonas insaturadas, glicosídeos fenólicos e cianogênicos, inibidores protéicos, fitotoxinas, quinases e $\beta-1,3$ glicanases). Os mecanismos pós-formados (ativos/induzíveis). estão ausentes ou presentes em baixos níveis antes da infecção, sendo induzidos em resposta à presença do patógeno (Pascholati \& Leite, 1995). Eles também podem estar subdivididos em estruturais (papilas, halos, lignificação, camadas de cortiça, tiloses) e bioquímicos (fitoalexinas, proteínas relacionadas à patogênese e a explosão oxidativa).

Dependendo da interação planta-patógeno, sinais moleculares do patógeno são reconhecidos pelo hospedeiro e transmitidos para o interior da célula, onde finalmente são traduzidos em uma resposta fisiológica. Normalmente, receptores vegetais reconhecem moléculas elicitoras, originárias do microrganismo invasor ou do próprio tecido hospedeiro danificado durante o processo de infecção (Dixon et al.,1994; Leite et al.,1997). Na transdução dos sinais moleculares primários pode ocorrer aumento do influxo de $\mathrm{Ca}^{+2}$, fosforilação e/ou desfosforilação de proteínas, geração de espécies ativas de oxigênio (EAOs) e síntese de ácido salicílico e de proteínas relacionadas à patogênese (RP). 
De uma maneira geral, a planta pode ser dividida em dois compartimentos separados por uma membrana plasmática contínua:

a) O compartimento intracelular, ou simplasto, o qual abriga todas as estruturas protoplasmáticas, incluindo os vasos do floema.

b) O compartimento extracelular, conhecido como apoplasto, o qual é composto dos espaços intercelulares e células mortas do vaso do xilema.

Embora a região apoplástica ocupe apenas $5 \%$ do volume total da parte aérea das plantas e do córtex da raíz (Grignon \& Sentenac, 1991), seu estudo é de grande importância, pois vários processos que regulam o desenvolvimento de interações planta-microrganismos ocorrem nesta local. Muitos dos mecanismos de defesa induzíveis envolvem a secreção de proteínas e outros metabólitos no apoplasto incluindo proteínas da matriz extracelular (Keller, 1993) e as proteínas RP (Stinzi et al., 1993).

As proteínas RP foram primeiramente relatadas em tabaco reagindo hipersensitivamente ao vírus do mosaico do tabaco (Van Loon \& Van Kammen, 1970, Kassanis et al., 1994). Com base nas propriedades serológicas, massa molecular, e seqüência de aminoácidos, as proteínas RP podem ser classificadas em 10 grupos. Elas são caracterizadas pela localização extracelular ou vacuolar em função de sua natureza ácida ou básica, respectivamente. Apenas dois grupos, RP-2 ( $\beta$-1,3-glucanases) e RP-3 (quitinases), apresentam atividades enzimáticas específicas. As quitinases e $\beta$-1,3-glucanases podem atuar na degradação da parede celular de fungos, e podem ser induzidas sistêmica e /ou localizadamente na planta, em resposta à infecção do patógenos (Carr \& Klessig, 1990). As proteínas dos grupos RP-1, 4 e 5 possuem grande potencial antifúngico, embora ainda faltem estudos mais específicos em relação aos mecanismos de ação dessas proteínas ou mesmo suas atividades catalíticas durante as respostas de defesa da planta (Niederman et al., 1995). 


\subsection{Análise de proteomas para o entendimento de interações planta- microrganismos.}

As proteínas produzidas por diferentes tipos celulares é o resultado final da expressão gênica. $O$ estudo de proteínas através da eletroforese bidimensional foi restrito, durante um certo período, pelas dificuldades na análise, incluindo a baixa resolução e reprodutibilidade. Com o desenvolvimento de novas matrizes e novas técnicas analíticas, a análise de proteomas por eletroforese bidimensional têm sido sensivelmente aprimorada e têm contribuído significativa para o estudo da fisiologia de vários organismos.

A técnica da eletroforese bidimensional resulta da combinação da focalização isoelétrica e a eletroforese em gel de poliacrilamida desnaturante (O` Farrell, 1975). As proteínas são separadas de acordo com seu ponto isoelétrico pela focalização isolétrica, na primeira dimensão. $\mathrm{Na}$ segunda dimensão, as proteínas são separadas de acordo com suas massas moleculares. Centenas de proteínas podem ser resolvidas em matriz de poliacrilamida, permitindo obter um mapa proteíco global para um determinado tipo celular. A eletroforese bidimensional tem sido utilizada para estabelecer mapas padrões de células, tecidos e modelos de desenvolvimento. A técnica também permite a comparação dos produtos proteícos produzidos por grupos celulares exposto à diferentes condições biológicas. A análise comparativa dos mapas gerados permite a identificação de proteínas com acúmulo diferencial, induzidas ou suprimidas sob diferentes condições (Guerreiro et al., 1997). A análise diferencial de

proteomas tem sido utilizada em estudos de interações simbióticas entre membros do gênero Rhizobium, Bradyrhizobium, Mesorhizobium, Sinorhizobium, Azorhizobium e plantas da famíla Leguminoseae (Guerreiro et al., 1997, Natera, et al., 2000). Outro exemplo de análise diferencial de proteomas, envolvendo interação planta-microrganismo, tem sido relatado em Xanthomonas axonopodis pv. citri e extrato de folhas de citros (Tahara, 
2000; Mehta, 2001). A eletroforese, acoplada ao seqüenciamento $\mathrm{N}$-terminal e espectometria de massa de peptídeos gerado por clivagem por proteases permite a identificação das proteínas de interesse (Wheeler et al., 1996; Wilkins et al.,1998). Atualmente, quantidades mínimas de proteínas, na faixa de picomoles, podem ser seqüenciadas, facilitando o estudo de sistemas biológicos onde a obtenção de grandes quantidades de proteína é limitante (Matsudaira, 1987). 


\section{MATERIAL E MÉTODOS}

\subsection{Amostragem}

\subsubsection{Experimento 1: Análise de variabilidade dos proteomas do fluído intercelular de folhas de laranjeiras de diferentes localidades}

A amostragem das folhas de laranjeiras, variedade pêra, foi feita em três regiões distintas. A primeira coleta foi realizada em uma fazenda comercial em Cordeirópolis, em 23.11.99. Foram coletadas folhas de laranjeiras de plantas não-infectadas e infectadas com Xf, apresentando sintomas característicos da CVC. A segunda coleta foi feita em 16.02.00, em uma área experimental da fazenda comercial de citros pertencente à Ricardo Esteves, em Gavião Peixoto, região centro do Estado de São Paulo. Nesta localidade foram coletadas folhas de plantas infectadas com Xf, com e sem sintomas de CVC. $\mathrm{Na}$ mesma data, amostras de plantas não-infectadas, cultivadas em casa-devegetação, foram coletadas no Centro de Citricultura do IAC, Cordeirópolis. A terceira coleta foi feita em 31.03.00, no pomar experimental do Departamento de Produção Vegetal da ESALQ, Piracicaba. Foram coletados folhas de plantas infectadas com Xf, com e sem sintomas de CVC.

\subsubsection{Experimento 2: Caracterização de proteínas do fluído intercelular de folhas de laranjeiras.}

As principais etapas do experimento 2 podem ser visto na Figura 1. $\mathrm{Na}$ segunda etapa do trabalho, as folhas de laranjeiras, foram coletadas na fazenda Cambuhy, em Matão (SP), em 20.06.01. Folhas não-infectadas com Xf foram coletadas de plantas cultivadas em borbulheira telada. Folhas infectadas com Xf com ou sem sintomas de CVC, foram coletadas no pomar. 


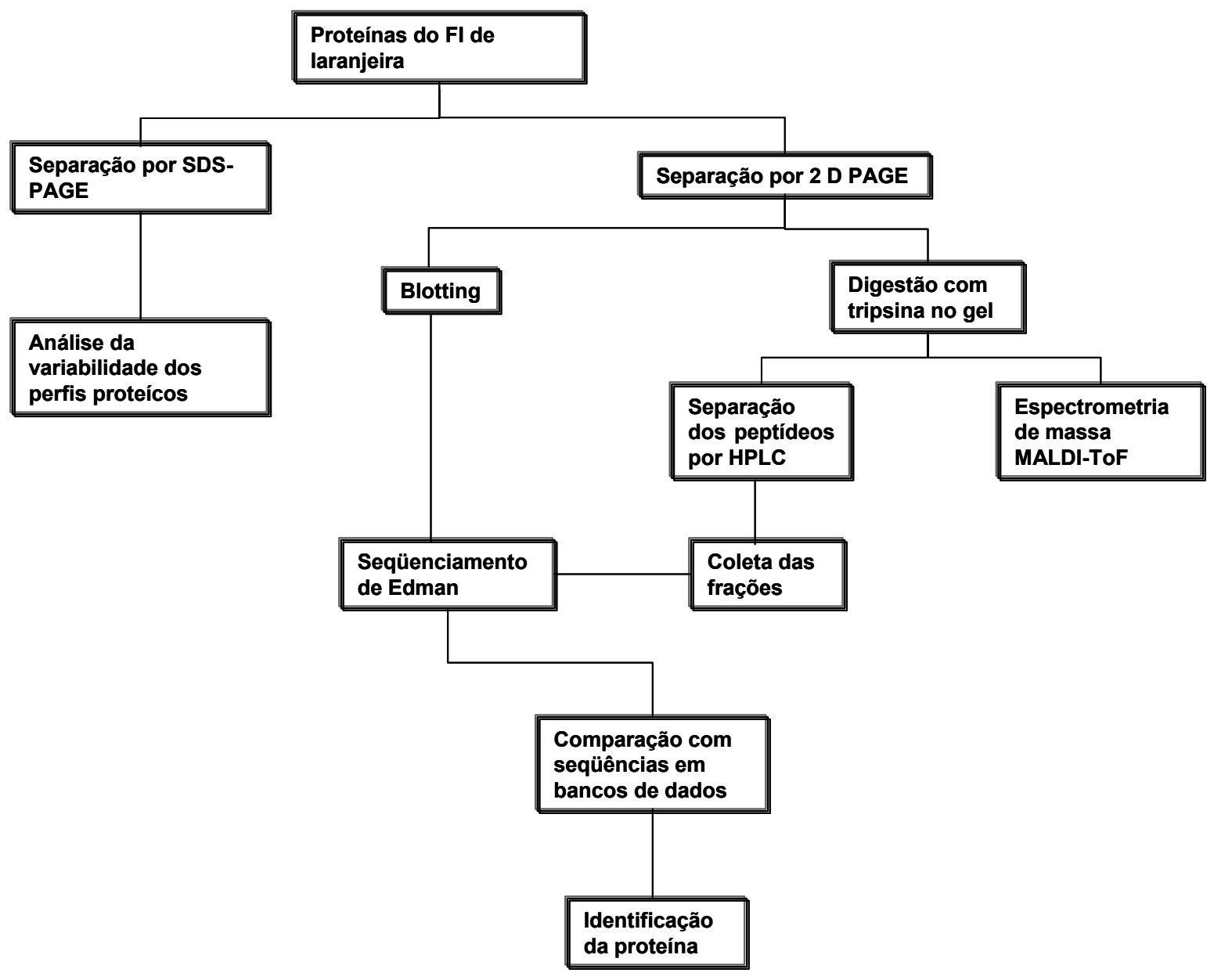

Figura 1 - Fluxograma indicando as principais etapas realizadas no estudo das proteínas $\mathrm{FI}$ de folhas de laranjeiras. 


\subsubsection{Extração do fluído intercelular}

\subsubsection{Experimento 1}

O fluído intercelular (FI) das folhas de laranjeiras foi extraído de acordo com Hammond-Kosack (1992), modificado. Maços de 15 folhas foram lavados e cortados em segmentos de $2,5 \mathrm{~cm}$ (Figura 2). Para a primeira parte do trabalho, as folhas foram infiltradas à vácuo com $d_{d d} \mathrm{H}_{2} \mathrm{O}$, à $4^{\circ} \mathrm{C}$. O FI foi extraído por centrifugação à $800 \mathrm{~g}$ por 10 minutos, à $4^{\circ} \mathrm{C}$. Para a remoção de microrganismos, o FI foi filtrado com filtro de $0,2 \mu \mathrm{m}$ de porosidade (Millipore ${ }^{\circledR}$ ). As amostras foram aliquotadas e armazenadas à $-20^{\circ} \mathrm{C}$.

\subsubsection{Experimento 2}

As folhas foram infiltradas com dd $\mathrm{H}_{2} \mathrm{O}$, contendo EDTA $1 \mathrm{mM}$ e PMSF $1 \mathrm{mM}$ (Barret \& Salversen, 1986; Granier, 1988). A extração do FI foi feita conforme descrita no item 3.2.1.1 As amostras foram aliquotadas $e$ armazenadas $\mathrm{a}-80^{\circ} \mathrm{C}$.

\subsection{Quantificação de proteínas}

A concentração de proteínas no $\mathrm{FI}$ foi determinada através do método de Bradford (1976), em microplacas, utilizando o Kit da BioRad para quantificação de proteínas (BioRad $\left.{ }^{\circledR}\right)$ e albumina de soro bovino como padrão.

\subsection{Determinação de contaminação citoplasmática}

A determinação de contaminação citoplasmática nos Fls foi feita através da atividade da glicose-6-desidrogenase, de acordo com Bergmeyer \& Grassl (1983), modificado. O ensaio foi feito em cubetas de quartzo, utilizandose $10 \mu \mathrm{l}$ de $\mathrm{FI}$ de cada amostra. Em $1 \mathrm{~mL}$ de solução contendo $0,38 \mathrm{mM}$ NADP, 0,05M Tris, 0,063M $\mathrm{MgCl}_{2}$ e 3,3mM glicose-6-fosfato, em $\mathrm{H}_{2} \mathrm{O}$. A cinética da reação.foi determinada a $339 \mathrm{~nm}$. Como controle positivo utilizou-se glicose-6fosfato desidrogenase pura (Boehringer-Mannheim). 
A
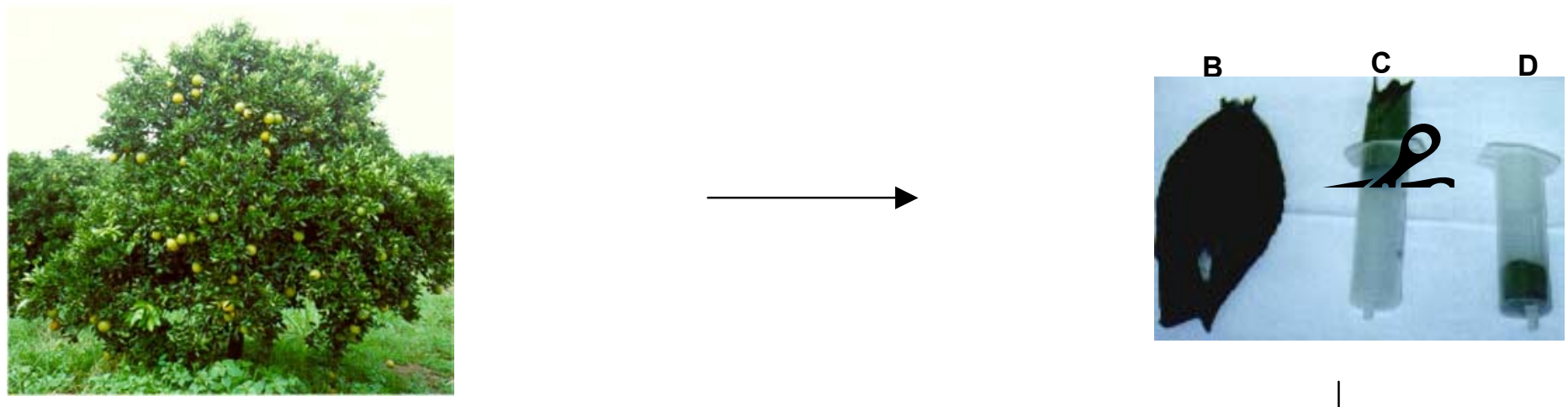

G
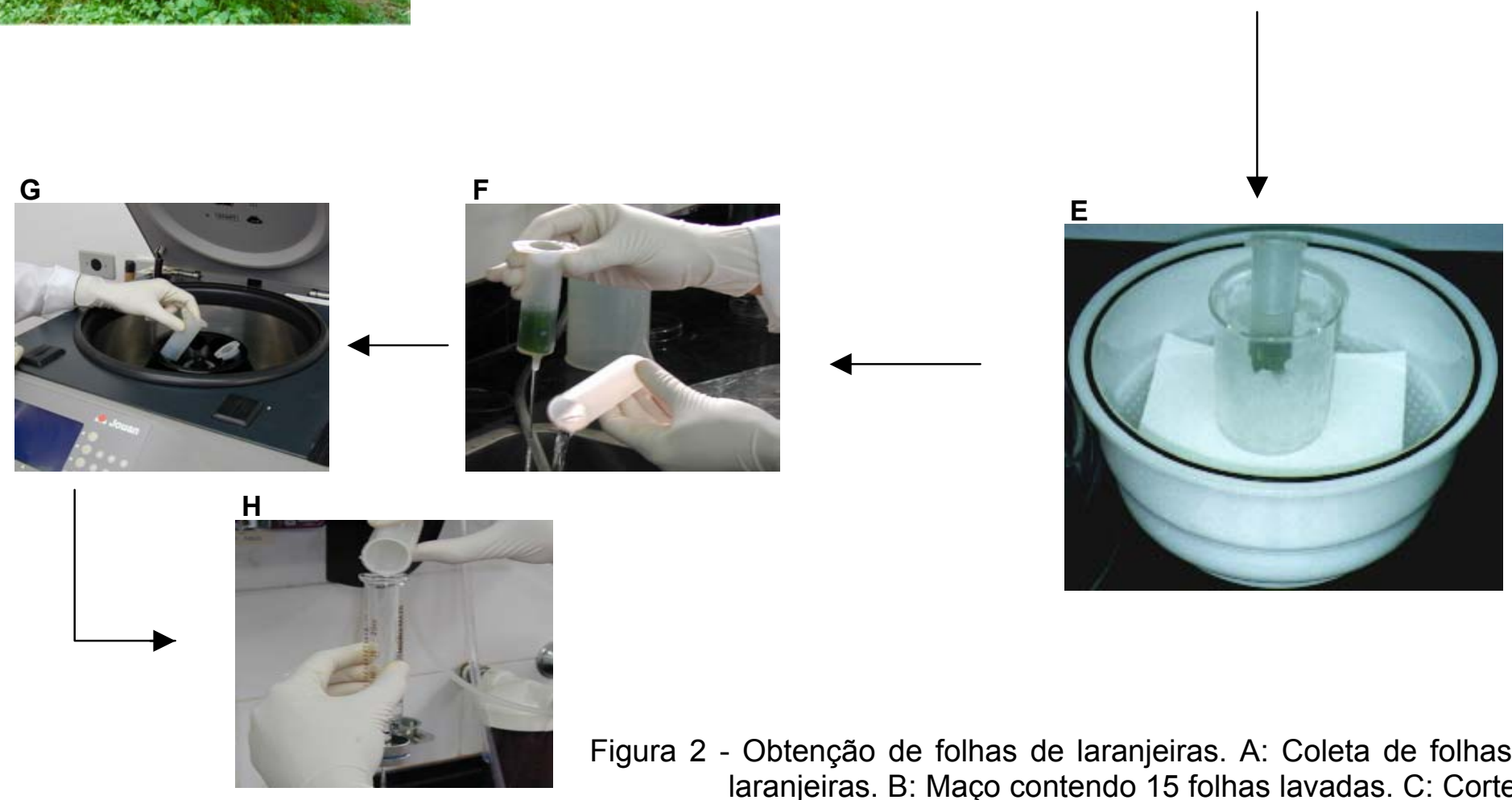

Figura 2 - Obtenção de folhas de laranjeiras. A: Coleta de folhas em árvores de laranjeiras. B: Maço contendo 15 folhas lavadas. C: Cortes de $2,5 \mathrm{~cm}$ em seringa de $50 \mathrm{~mL}$. D: Segmentos de folhas prontos para infiltração. E: Infiltração das folhas com $d_{d H_{2}} \mathrm{O}$ e inibidores de protease à vácuo e à $4^{\circ} \mathrm{C}$. F: Remoção da solução de $\mathrm{dd}_{2} \mathrm{O}$ com inibidores de protease. G: Centrifuaacão das folhas. H: Filtracão com filtro 0.2 um. 


\subsection{Confirmação da presença ou ausência do patógeno}

A extração do DNA foi feita a partir do pecíolo, utilizando-se o Kit Fast DNA ${ }^{\circledR}$, em conjunto com o FP120 FastPrep ${ }^{\mathrm{TM}}$ Cell Disruptor (Bio 101, Vista, Califórnia), conforme as instruções do fabricante. A concentração de DNA total foi determinada por espectrofotometria à $260 \mathrm{~nm}$.

A confirmação da presença ou ausência de Xf nas folhas amostradas foi feita através de PCR, utilizando-se oligonucleotídeos iniciadores específicos, originários de uma seqüência intergênica da Xylella fastidiosa conforme descrito por Pooler \& Hartung, (1995). Em cada reação utilizou-se aproximadamente 20ng de DNA em 25 $\mu$ l de solução tampão PCR 1x (Pharmacia), contendo $0,4 \mu \mathrm{M}$ dos iniciadores CVC-1(5'-AGATGAAAACA ATCATGCAAA-3') e CVC

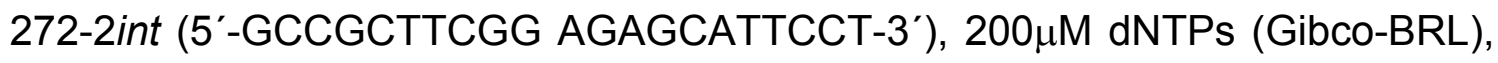
e 1,0U de DNA polimerase Taq (Pharmacia). A amplificação foi realizada em um ciclo de $3 \mathrm{~min}$. à $94^{\circ} \mathrm{C}$, e 35 ciclos de 1 minuto à $94^{\circ} \mathrm{C}, 1$ minuto à $50^{\circ} \mathrm{C}, 1$ minuto à $72^{\circ} \mathrm{C}$, seguidos de um período de extensão de 4 minutos à $72^{\circ} \mathrm{C}$. Como controle positivo foi utilizado DNA de Xf estirpe 9a5c, utilizada no Projeto Genoma, Xylella fastidiosa, e como controle negativo foi utilizado $\mathrm{dd}_{2} \mathrm{O}$. O fragmento amplificado foi analisado em gel de agarose $1 \%$ - TBE. A eletroforese foi realizada à $70 \mathrm{~V}$ constante em tampão $0,5 \mathrm{X}$ TBE $(400 \mathrm{mM}$ Tris, $400 \mathrm{mM}$ ácido bórico, $10 \mathrm{mM}$ EDTA) e as bandas de DNA visualizadas por coloração com brometo de etídio $\left(0,5 \mu \mathrm{gmL}^{-1}\right)$ ou Sybr Green (1v:1000v). A aquisição das imagens dos géis foi feita utilizando-se um densitômetro a laser "FluorlmageSI" (Amersham Biotech Pharmacia).

\subsection{Análise dos proteomas do Fls}

\subsubsection{Experimento 1}

$\mathrm{O}$ equivalente a $2 \mu \mathrm{g}$ de proteínas do $\mathrm{FI}$ foram precipitadas com 5 volumes de uma solução de acetona acidificada (1vol acetona:0,001 vol $\mathrm{HCl}$ : 1 vol metanol), por 12 horas à $-20^{\circ} \mathrm{C}$ (Marshak et al., 1996). As proteínas 
precipitadas foram peletizadas à $15000 \mathrm{~g}$ durante 30 minutos, à $4^{\circ} \mathrm{C}$. A solução de acetona foi descartada e as proteínas foram resolubilizadas em $10 \mu \mathrm{l}$ de solução tampão de carregamento $(62,5 \mathrm{mM}$ Tris-HCl, $20 \%$ glicerol, $2 \%$ SDS, $5 \%$ $\beta$-mercaptoetanol, 0,05\% azul de bromofenol). As amostras foram aquecidas à $95^{\circ} \mathrm{C}$ por 3 minutos, e submetidas à eletroforese em géis de poliacrilamida $15 \%$ SDS (10x10,5 cm x 0,75 mm de espessura), em tampão de corrida 1x Trisglicina (25mM Tris, $192 \mathrm{mM}$ glicina, 0,1\% SDS), à 100V constante por 3 horas. As proteínas foram coradas com prata utilizando-se o Kit Silver Staining (Amersham Pharmacia Biotech), conforme as instruções do fabricante. Os géis foram analisados por densitometria, utilizando-se um densitômetro laser Personal Densitometer SI (Molecular Dynamics) e o programa Fragment Analysis (Molecular Dynamics).

\subsubsection{Experimento 2}

\subsubsection{Focalização isoelétrica.}

Quarenta microgramas de proteínas, obtidos por precipitação com acetona acidificada, foram solubilizadas em solução $50 \mathrm{mMT}$ ris- $\mathrm{HCl}(\mathrm{pH} 8,8)$, $100 \mathrm{mMDTT}, 0,5 \%$ SDS. Essa solução foi aquecida à $95^{\circ} \mathrm{C}$ por 5 minutos e adicionada a solução contendo 8M uréia, 4\% CHAPS, 70mM DTT, 0,8\% ampholinas (IPG buffer, pH 3-10 não-linear, Amersham Pharmacia Biotech), 0,005\% azul de bromofenol. A solução foi agitada por 1 minuto, seguido de 1 hora de descanso, e depois novamente agitada por mais 1 minuto. Dois $\mathrm{mL}$ de óleo mineral ("Fluid Cover", Amersham Pharmacia Biotech) foram colocados sobre as fitas IPG para se evitar a evaporação dos reagentes durante a rehidratação. As fitas IPG de $18 \mathrm{~cm}$ com gradiente de $\mathrm{pH}$ 3-10 não-linear foram rehidratadas no aparato para a focalização isoelétrica (IPGphor, Amersham Pharmacia Biotech) durante 14 horas, em temperatura ambiente.

No primeiro estágio de focalização isoelétrica utilizou-se 150V durante 1 hora; no segundo estágio utilizou-se $350 \mathrm{~V}$ durante 1 hora; no terceiro estágio, 
$500 \mathrm{~V}$ por 1 hora; no quarto estágio 1000V, por 1 hora; no quinto estágio 5000V, por 12 horas ou até atigir $60 \mathrm{kVh}$. Depois da focalização isoelétrica, as fitas IPG foram lavadas com $\mathrm{dd}_{2} \mathrm{O}$, equilibradas em duas soluções redutoras de pontes de dissulfetos. A primeira solução de equilíbrio era composta por $50 \mathrm{mM}$ Tris-

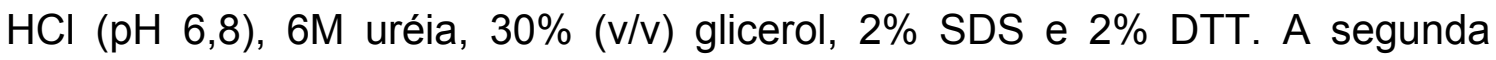
solução era composta por $50 \mathrm{mM}$ de Tris- $\mathrm{HCl}(\mathrm{pH} \mathrm{6,8)}$ ), 6M uréia, 30\% (v/v) glicerol, 2\% SDS, 2,5\% iodoacetamida (Görg et al., 1987) e 0,05\% azul de bromofenol. As fitas IPG foram equilibradas por 12 minutos em cada solução.

\subsubsection{SDS-PAGE}

A segunda dimensão da eletroforese foi feita em um gel vertical homogêneo de acrilamida, com sistema descontínuo, conforme descrito por Laemmli (1970), modificado. O gel foi preparado com 12,5\% Bis-acrilamida (37,5:1, m:m), 1,5M Tris (pH 8,8), 0,1\% persulfato de amônia, e 0.05\% TEMED. Depois de equilibradas, as fitas IPG foram colocadas sobre o gel da segunda dimensão e cobertas com uma solução $0,5 \%$ de agarose em tampão Trisglicina (25mM Tris-HCl, 192mM glicina, e 0,1\% SDS). O tampão de corrida

utilizado foi Tris-glicina. A separação eletroforética das proteínas foi feita à $10^{\circ} \mathrm{C}$, em cuba SE 600 (Amersham Pharmacia Biotech). Na primeira etapa, utilizou-se $90 \mathrm{~V}$ fixos durante 30 minutos. Na segunda etapa, utilizou-se $30 \mathrm{~mA}$ por gel durante aproximadamente 3 - 4 horas. Em seguida, os géis foram lavados em $\mathrm{dd}_{2} \mathrm{O}$ por 5 minutos, e as proteínas coloridas com prata.

\subsubsection{Coloração das proteínas por impregnação com prata}

A coloração das proteínas foi efetuada segundo Blum et al. (1987), modificado. As soluções foram preparadas imediatamente antes do uso e utilizadas seqüencialmente, conforme descrito a seguir. Solução fixadora ( $50 \%$ metanol, $12 \%$ ácido acético $0,028 \%$ formaldeído) por $12 \mathrm{~h} ; 50 \%$ etanol, $3 \mathrm{x}$ 20 min; solução de sensibilização ( $0,2 \%$ tiossulfato de sódio) por $1 \mathrm{~min} ; \mathrm{ddH}_{2} \mathrm{O}$, $3 \times 20$ s; solução de impregnação $(0,2 \%$ nitrato de prata; $0,028 \%$ formaldeído) 
por 20 min; $\mathrm{ddH}_{2} \mathrm{O}, 3 \times 20$ s; solução reveladora (6\% carbonato de sódio; $0,4 \%$ tiossulfato de sódio; $0,018 \%$ formaldeído) até o aparecimento dos pontos; solução de paralização (5\% ácido acético) por $10 \mathrm{~min}$.

\subsubsection{Aquisição de imagens}

As imagens dos géis foram obtidas por varredura, utilizando um densitômetro a laser ("Personal Densitometer SI"- Molecular Dynamics). As análises dos géis foram feitas com o programa ImageMaster 2D versão 3.10 (Amersham Pharmacia Biotech). As massas moleculares aparente das proteínas foram determinadas utilizando padrões de massa moleculares ("BroadRange" - Molecular Weight Marker, BioRad). Como padrão de ponto isoelétrico $(\mathrm{pl})$ foram utilizados dados gerados pela análise do mapa teórico do proteoma total da Xf (Laboratório de Química de Proteínas-UNICAMP).

\subsubsection{Transferência das proteínas para membrana, seqüenciamento da extremidade $\mathbf{N}$-terminal e análise das seqüências de aminoácidos}

As proteínas foram transferidas para membrana de polivinildifluoretoPVDF (Hybond-P, Amersham Pharmacia Biotech) utilizando tampão de corrida 10mM CAPS $(\mathrm{pH} 11)$ em 10\% metanol (v/v). A transferência foi realizada a 400mA constante por um período de 3 horas. A seguir, as proteínas na membrana PVDF foram coradas com 0,1\% Coomassie Brillant Blue R-250 em metanol 50\%, por 1 minuto e descoradas em $40 \%$ metanol, $10 \%$ ácido acético por 2 minutos. As membranas foram lavadas em $\mathrm{ddH}_{2} \mathrm{O}$ e em seguida secas sob corrente de ar quente. Os pontos de interesse foram removidos das membranas (Figura 3 ) e a seqüência de aminoácido $\mathrm{N}$-terminal foi determinada em um seqüenciador PROCISE (Perkin-Elmer Applied Biosystems, Foster City, CA) no LAQUIP-UNICAMP. A comparação das seqüências dos peptídeos com seqüências em bancos de dados públicos não-redundantes foi feita com programa BLAST (Altschul et al., 1997). 


\subsubsection{Digestão das proteínas com tripsina e preparação para espectometria de massa.}

A espectometria de massa (MALDI-ToF) foi utilizada para determinar e comparar as massas de peptídeos geradas por digestão com tripsina de seis proteínas de mesma massa molecular aparente (Figura 4, 1a-f ). Após a eletroforese, as proteínas foram coradas com Coomassie Blue R-250 (Bio-Rad), $50 \%$ metanol e $10 \%$ ácido acético e descoradas com $40 \%$ metanol e 10\% ácido acético. A digestão tríptica das proteínas no gel foi efetuada segundo Rosenfeld et al. (1992) e Jenö et al. (1995), modificado. Foi adicionado aos fragmentos do gel, contendo as proteínas de interesse, $100 \%$ acetonitrila e incubado por 10 minutos. Esse procedimento foi repetido por duas vezes. O resíduo de acetonitrila foi evaporado utilizando um evaporador rotativo Speed Vac Plus, Savant. Em seguida, os fragmentos do gel foram imersos em uma solução de $250 \mu \mathrm{gmL}^{-1}$ tripsina em $50 \mathrm{mM}$ bicarbonato de amônio e incubados por 40 minutos no gelo. Em seguidas, os tubos foram colocados em banho-maria por 12 horas. A ação da tripsina foi bloqueada com uma solução acetonitrila $50 \%$ e $5 \%$ ácido fórmico. Foi acrescentado, então $20 \mathrm{mM}$ bicarbonato de amônio e incubado por 30 minutos. A solução foi recolhida em um novo eppendorf. Os peptídios foram retirados da matriz de acrilamida com três lavagens de 10 minutos com $50 \%$ acetonitrila e $5 \%$ ácido fórmico. Os peptídos extraídos armazenados em eppendorfs, e foram posteriormente sonicados por 10 minutos. O excesso de acetonitrila foi evaporado no Speed Vac Plus (Savant). Um décimo do volume da amostra foi purificado usando ZipTip C18 (Millipore ${ }^{\circledR}$ ) e misturado com $60 \%$ acetonitrila e $0,1 \%$ ácido trifluoroacético (TFA). As amostras foram misturadas na proporção 1:1 com matriz $\alpha$-ciana (CHCA), e alíquotas de $1 \mu \mathrm{l}$ foram aplicadas na placa de leitura do espectrometro de massa Voyager $^{\mathrm{TM}}$ Biopectrometry (Applied Biosystems) operando em modo refletor, positivo. A calibração externa foi feita com albumina bovina. A leitura das massas de peptídeos foi realizada no LAQUIP, UNICAMP. 


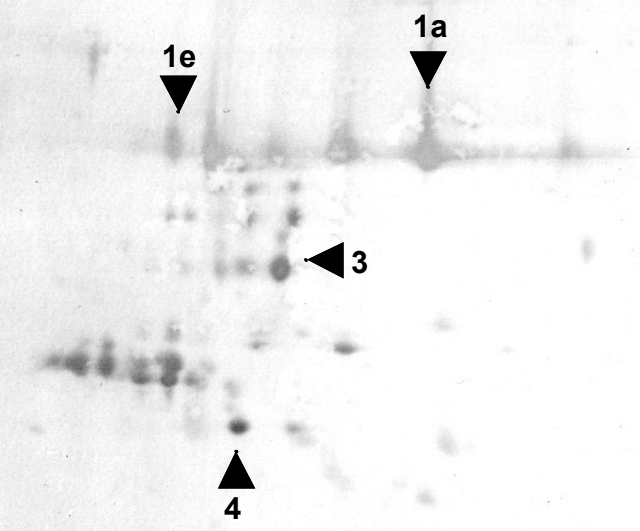

5

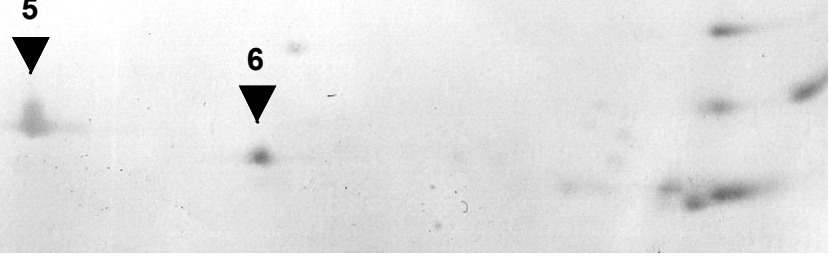

Figura 3 - Membrana de PVDF corada com Coomassie referente ao FI de folhas não-infectada. As setas e os números indicam proteínas que já foram ou serão submetidas ao seqüenciamento $\mathrm{N}$-terminal. 


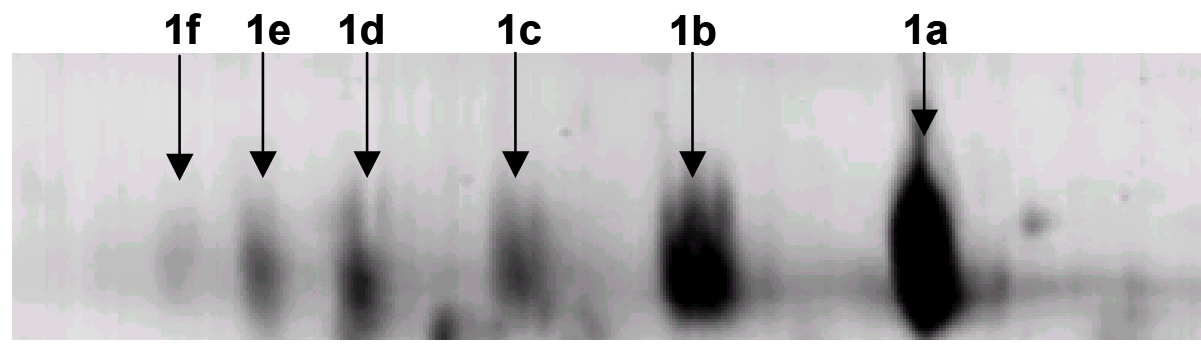

Figura 4 - Detalhe das isoformas de proteína de $41 \mathrm{kDa}$ do $\mathrm{FI}$ de folhas de laranjeiras. As proteínas foram coradas com Coomassie blue. a$f$ representam as isoformas que foram retiradas da matriz de poliacrilamida para digestão tríptica. 


\subsubsection{Separação dos peptídeos das isoformas utilizando cromatografia} líquida de alta pressão de fase reversa .

O restante dos peptídeos eluídos da matriz de acrilamida foram separados em uma coluna $\mu$ Bondapak ${ }^{\mathrm{TM}} \mathrm{C} 18(7,8 \times 300 \mathrm{~mm}$, Waters $)$ de fase reversa. A coluna foi eluída com um gradiente linear de $0,1 \%$ TFA (solução $A$ ) $66 \%$ acetonitrila em $0,1 \%$ TFA (solução $B$ ). A taxa de fluxo utilizada foi de $1 \mathrm{mLmin}^{-1}$. Gradiente utilizado foi: 2 min. $0 \%$ solução B; 2 min. $0-20 \%$ B; 14 min. $20-50 \%$ B; 7 min. $50-80 \%$ B; 5 min. $80 \%$ B. A eluição foi monitorada à um comprimento de onda de $280 \mathrm{~nm}$ e as frações foram manualmente coletados. A análise do cromatograma foi feita utilizando-se o programa Millennium ${ }^{32}$ Chromatography Mananger ${ }^{\mathrm{TM}}$ (Waters).

\subsubsection{Seqüenciamento dos peptídeos internos das isoformas.}

As frações de 2, 4 e 5 obtidos por HPLC de fase reversa (Figura 5) foram concentradas e suas seqüências de aminoácidos determinada por degradação de Edman, utilizando-se um seqüenciador PROCISE (Perkin-Elmer Applied Biosystems) (LAQUIP-UNICAMP). 


\section{RESULTADOS E DISCUSSÃO}

\subsection{Determinação de contaminação citoplasmática}

Os Fls extraídos nesses experimentos não apresentaram atividade de glucose-6-P-desidrogenase, indicando que não houve ruptura das células durante os procedimentos de infiltração e extração (dados não apresentados), e que as proteínas no FI são apoplásticas.

\subsection{Confimação da presença ou ausência do patógeno}

As amostras de DNA de plantas infectadas, e com sintomas de CVC, quando sujeitas a PCR com o conjunto de iniciadores CVC1 e CVC 272-2int, produziram um fragmento de aproximadamento $500 \mathrm{pb}$ (Figura 6). As amostras de DNA de plantas não-infectadas não apresentam produtos de amplificação, indicando que Xf não estava presente nas folhas amostradas amplificação. A amplificação do DNA de plantas infectadas sem sintomas de CVC também produziram o fragmento esperado, exceto as amostas 22 e 31 . Quanto a amplificação do DNA das amostras 22 e 31 foi feita utilizando-se os iniciadores PRBA338f e PRUN518r, os quais amplificam um fragmento de aproximadamento $200 \mathrm{pb}$ do rDNA $16 \mathrm{~S}$ de eubactérias, os resultados foram positivos (dados não apresentados), indicando que o DNA dessas amostras é amplificável. Esses dados sugerem que as folhas amostradas não estavam infectadas com Xf, muito embora tenha sido retiradas de árvores com alto grau de infecção (com base nos sintomas observados em outras partes das plantas), ou que a população de Xf nessas folhas está abaixo do limite de detecção da metodologia empregada, já que os proteomas do FI dessas amostras diferem daquele das plantas não-infectadas com Xf (ver item 4.3). 


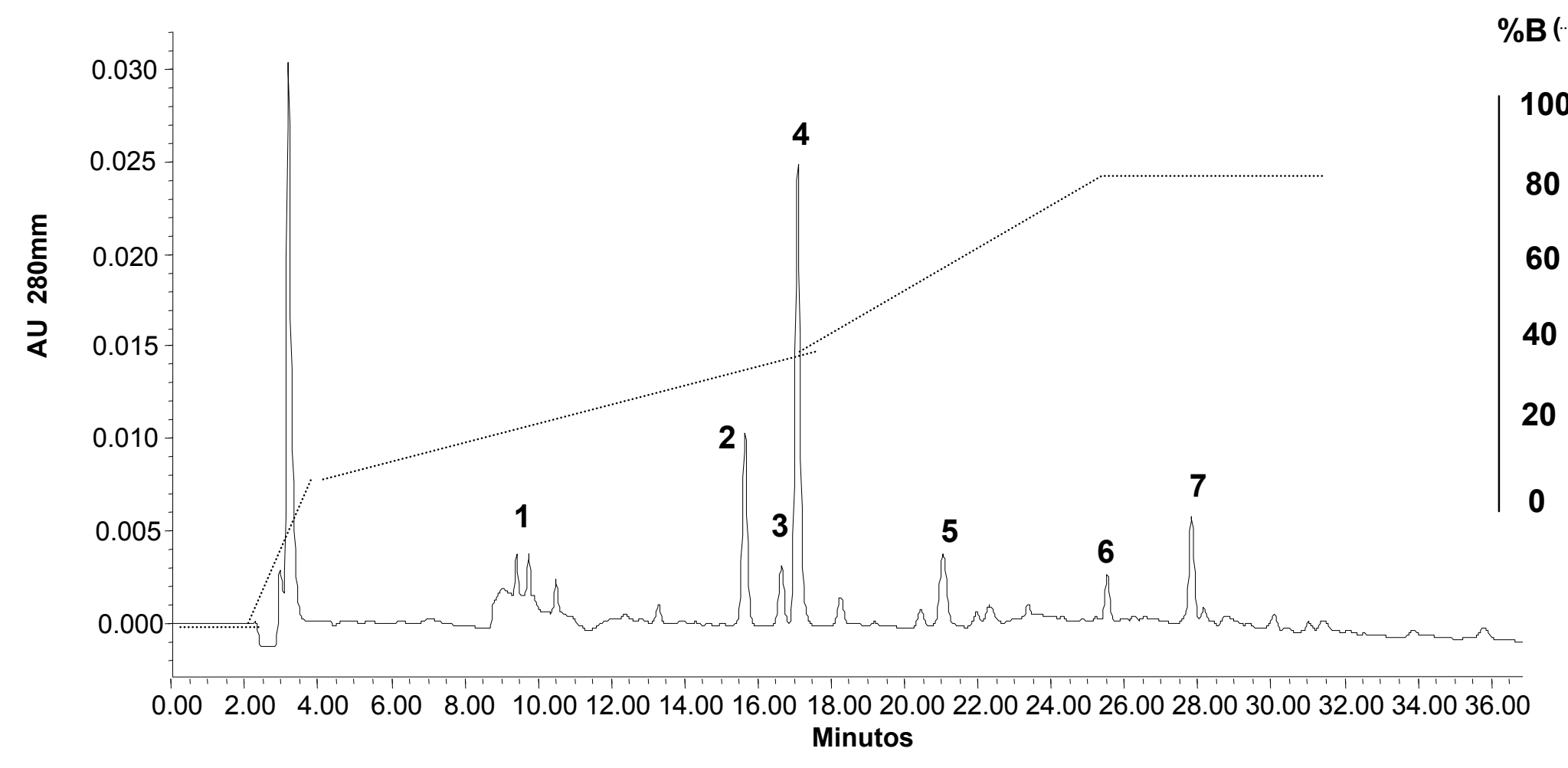

Figura 5 - Cromatograma dos peptídeos gerados por digestão tríptica das isoformas 1 a-f de $\mathrm{FI}$ de folhas de laranjeiras não-infectadas. Os pico 2, 4 e 5 foram submetidos a seqüenciamento $\mathrm{N}$-terminal. Parâmetros cromatográficos: solvente A: $0,1 \%$ TFA; solvente $B$ : $66 \%$ acetonitrila, $0,1 \%$ TFA; volume injetado $200 \mu \mathrm{l}$; fluxo $1 \mathrm{mLmin}^{-1}$; Gradiente: $2 \mathrm{~min}$. 0\% B; 2 min. 0-20\% B; $14 \mathrm{~min}$. 20-50\% B; 7 min. $50-60 \%$ B; 5 min. $80 \%$ B 

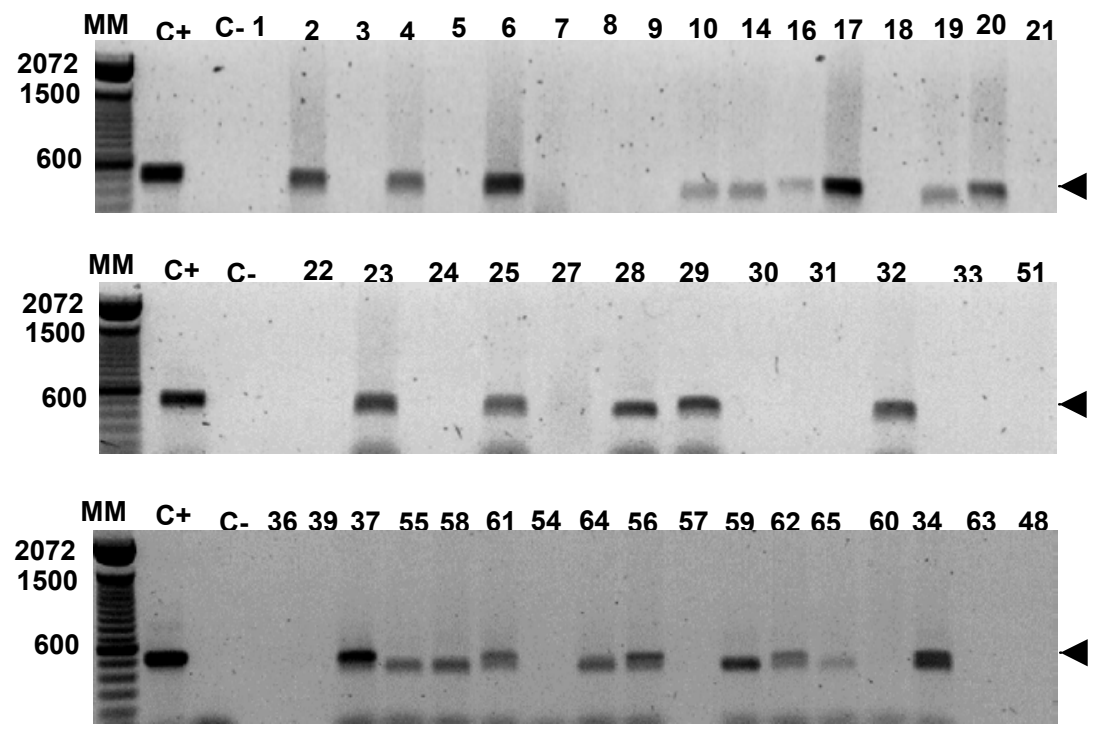

Figura 6 - Eletroforese em gel de agarose dos produtos da amplificação do DNA de pecíolo de citros infectados ou não com Xylella fastidiosa por PCR utilizando os iniciadores específicos CVC-1 e CVC 272-2int. C+: Controle positivo (DNA de Xf 9a5c). C-: Controle negativo $\left(\mathrm{ddH}_{2} \mathrm{O}\right)$. 1, 3, 5, 7, 8: plantas nãoinfectadas, Cordeirópolis. 2, 4, 6: plantas infectadas com sintomas, Cordeirópolis. $9,18,21,24,27,30,33,36,39,48,51$ : plantas nãoinfectadas-IAC-Cordeirópolis. 10, 16, 19, 22, 25, 28, 31, 34, 37: plantas infectadas sem sintomas, Gavião Peixoto. 14, 17, 20, 23, 29, 32: plantas infectadas com sintomas, Gavião Peixoto. 54, 57, 60, 63: plantas nãoinfectadas, ESALQ. 55, 58, 61, 64: plantas infectadas sem sintomas, ESALQ. 56, 59, 62, 65: plantas infectadas com sintomas, ESALQ. O fragmento esperado é indicado pela seta. 
Os resultados da amplificação do DNA extraído do pecíolo das folhas, provindas do pomar de citros pertencente a fazenda Cambuhy, podem ser visto na Figura 7. O fragmento amplificado, utilizando os iniciadores CVC-1 e CVC 272-2int, das amostras de DNA das plantas infectadas sem sintomas e infectadas com sintomas, confirma a presença de Xf. As amostras de plantas provindas da borbulheira telada não apresentaram o fragmento específico, indicando assim, a ausência da Xf .

\subsection{Análise da variabilidade dos proteomas do FI de folhas de laranjeira de diferentes localidades}

As Figuras 8 e 9 representam os perifis de proteínas do $\mathrm{FI}$ de folhas de laranjeira de Cordeirópolis, Gavião Peixoto e ESALQ. As proteínas do FI apresentam massa molecular aparente variando aproximadamente $10 \mathrm{kDa}$ a $100 \mathrm{kDa}$. As proteínas de $41 \mathrm{kDa}$ e $42 \mathrm{kDa}$ são as mais abundantes no $\mathrm{FI}$ de plantas não-infectadas, representando $34 \%$ e $24 \%$ respectivamente, do total de proteínas do $\mathrm{FI}$. As proteínas de $27 \mathrm{kDa}$ e $14 \mathrm{kDa}$ também são abundantes representando $7 \%$ e $5 \%$, respectivamente, do total de proteínas do FI de plantas não-infectadas.

A análise de discriminante, com base na ocorrência de proteínas e sua abundância relativa, indica que os proteomas do FI de folhas coletadas em locais diferentes são distintos (Figura 10). Com base nos dados obtidos, podemos concluir que as amostras da ESALQ são as que mais diferem das demais, muito embora as amostras de Cordeirópolis, Gavião Peixoto e Cordeirópolis/IAC sejam estatisticamente distintas (Figura 10). Essa diferença no proteoma do FI de plantas de diferentes localidades, pode ser explicada pelas diferenças nas condições climáticas, edáficas e manejo das culturas existentes nos locais de amostragem, bem como diferenças no genoma das laranjeiras, já que elas não apresentam o mesmo genótipo.

A análise discriminante do $\mathrm{FI}$, com base no fenótipo das folhas indica que os perfis de proteínas de plantas não-infectadas e infectadas com sintomas 

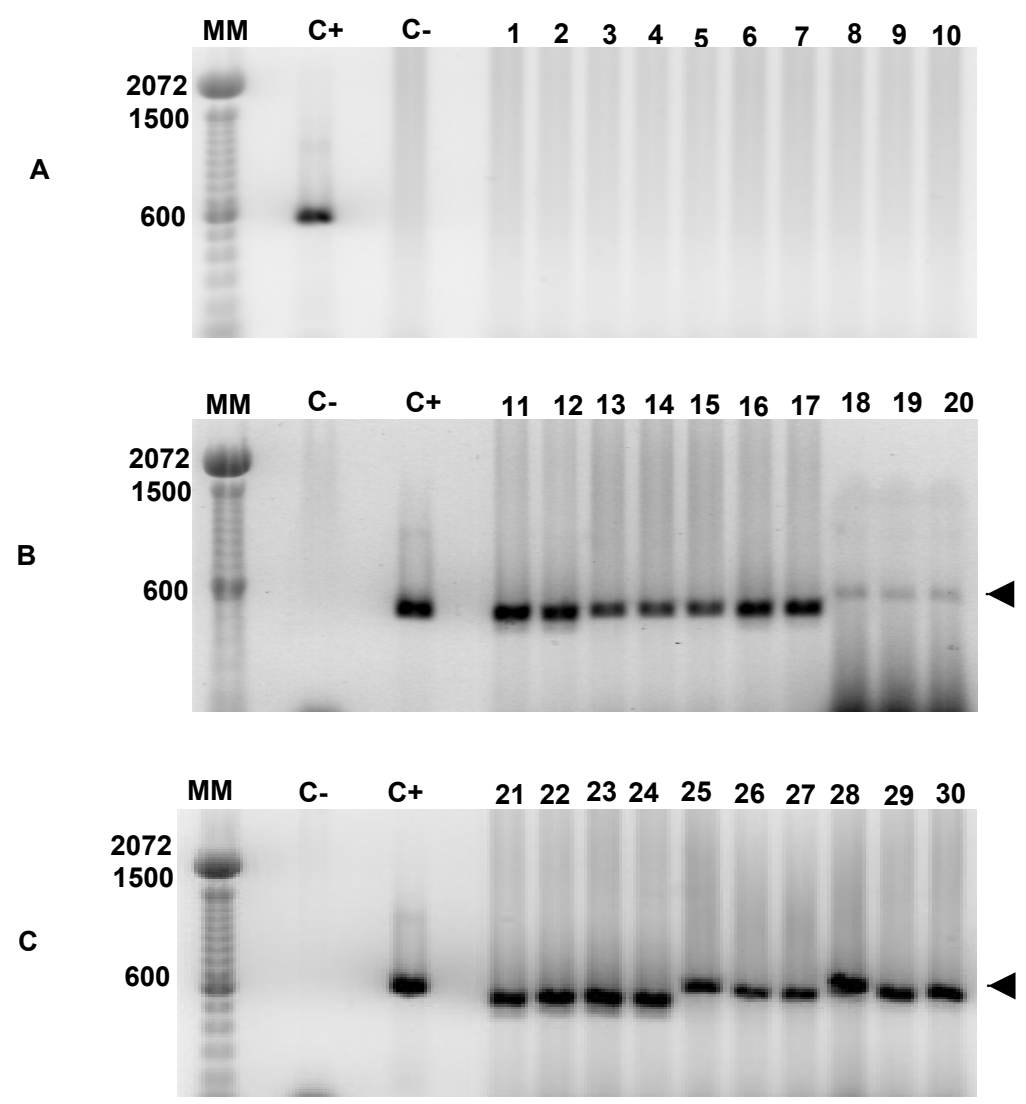

Figura 7 - Eletroforese em gel de agarose dos produtos da amplificação do DNA de pecíolo de laranjeiras infectados ou não com Xylella fastidiosa por PCR utilizando iniciadores específicos CVC-1 e 272-2int. C+: Controle positivo (DNA de Xf 9a5c). C-: Controle negativo $\left(\mathrm{ddH}_{2} \mathrm{O}\right)$. A. 1 a 10: plantas seminfecção. Borbulheira-Fazenda Cambuhy-Matão. B. 11 a 20: plantas infectadas sem sintomas, Cambuhy-Matão. C. 21 a 30: plantas infectadas com sintomas, Cambuhy-Matão. O fragmento esperado é indicado pela seta. 

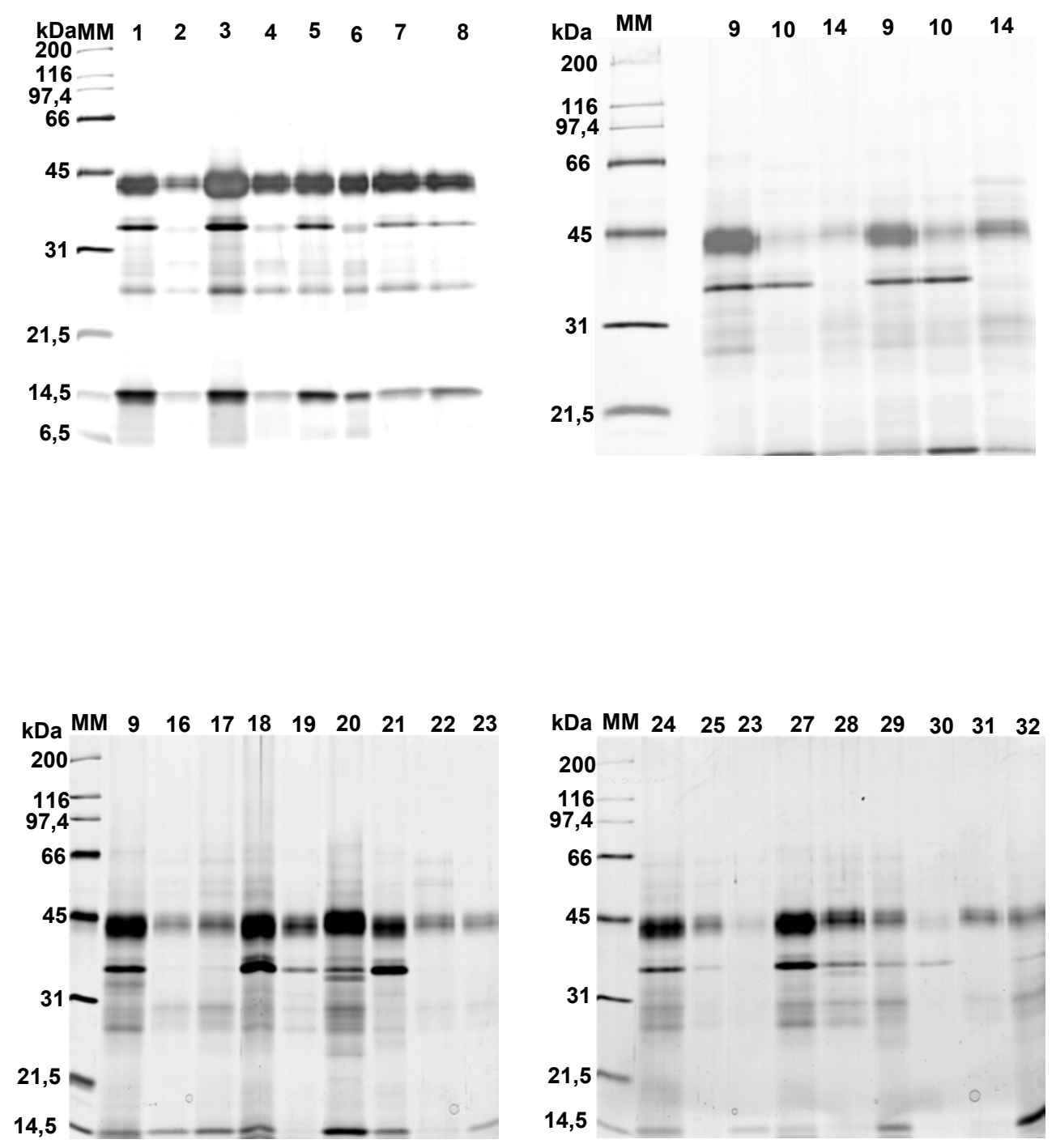

Figura 8 - Perfil de proteínas do FI de folhas de laranjeira em géis de poliacrilamida (15\%) desnaturantes. Quantidades iguais de proteínas foram utilizadas $(2 \mu \mathrm{g})$. MM marcador de massa molecular. 1, 3, 5, 7, 8: plantas não-infectadas com XfCordeirópolis. 2, 4, 6: plantas infectadas com Xf e com sintomas de CVCCordeirópolis. 9, 18, 21, 24, 27, 30: planta não-infectada com Xf, IACCordeirópolis. 10, 16, 19, 22, 25, 28, 31: plantas infectadas sem sintomas de CVC, Gavião Peixoto. 14, 17, 20, 23, 29, 32: plantas infectadas com sintomas de CVC, Gavião Peixoto. 

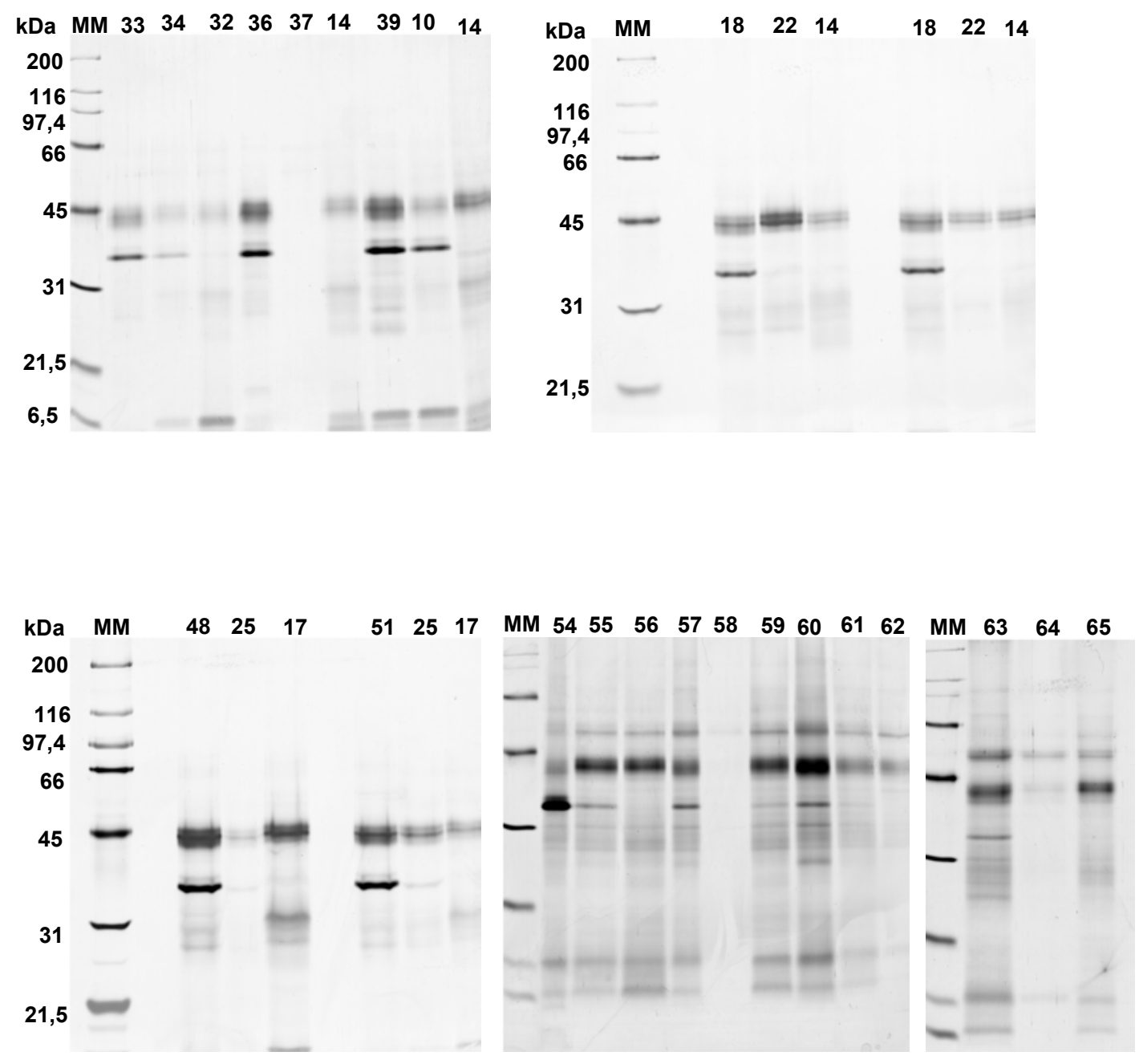

Figura 9 - Perfil de proteínas do FI de folhas de laranjeira em géis de poliacrilamida (15\%) desnaturantes. Quantidades iguais de proteínas foram utilizadas $(2 \mu \mathrm{g})$. MM marcador de massa molecular. 18, 33, 36, 39, 48, 51: plantas não-infectadas com Xf, IAC-Cordeirópolis. 10, 22, 25, 34, 37 plantas infectadas sem sintomas de CVC-Gavião Peixoto. 14, 1732 plantas infectadas com sintomas de CVCGavião Peixoto. 54, 57,60, 63 plantas não-infectadas com Xf-ESALQ. 55, 58, 61, 64 plantas infectadas sem sintomas de CVC-ESALQ. 56, 59, 62, 65: plantas infectadas com sintomas de CVC-ESALQ. 


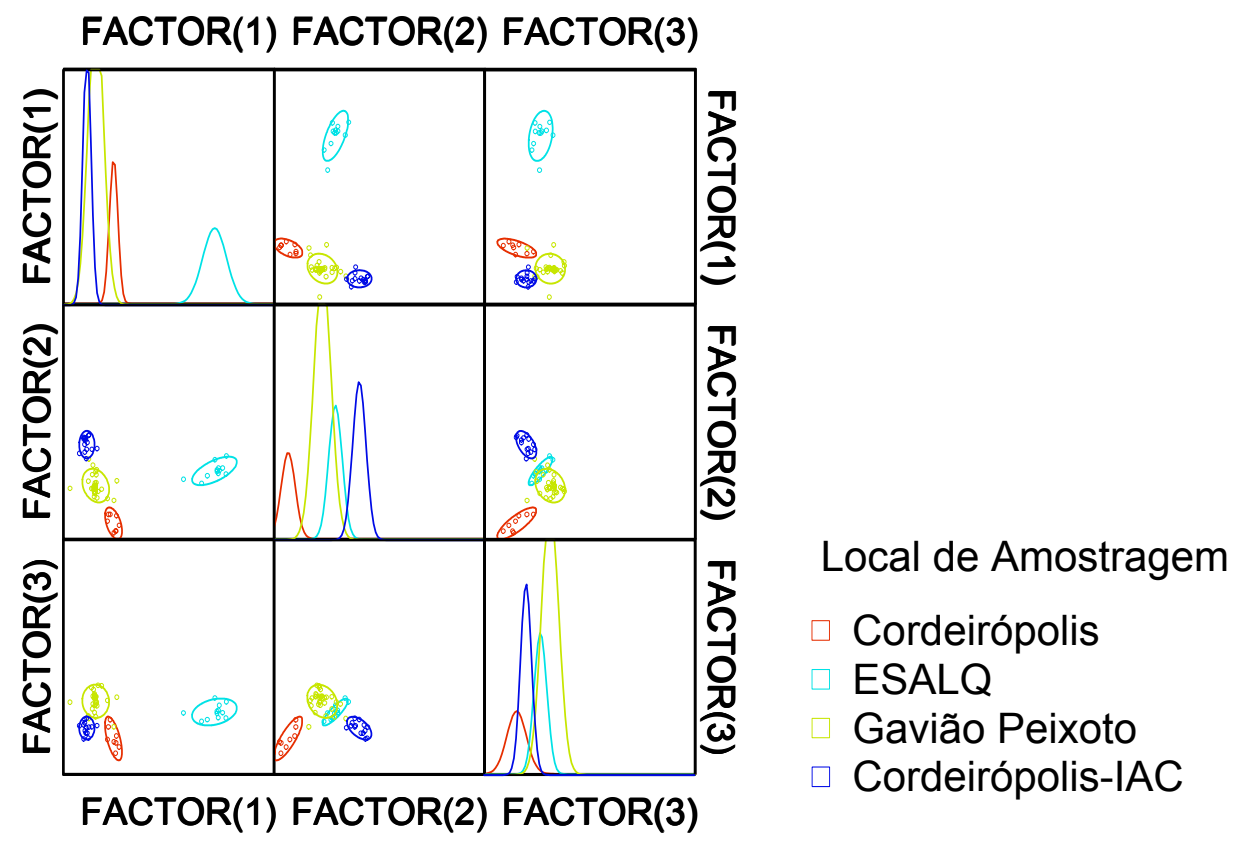

Figura 10 - A análise discriminante de amostras do FI de folhas de laranjeiras coletadas em diferentes localidades, com base na ocorrência e abundância relativa de proteínas detectadas através de eletroforese em gel de poliacrilamida (15\%) e coloração com prata. As elipses representam o intervalo de confidência $(p<0,05)$ de probabilidade). Fator(1), Fator(2) e Fator(3) são as variáveis canônicas. 
são estatisticamente distintos, independente do local de amostragem (Figura 11).

\subsection{Caracterização das proteínas do FI pela eletroforese bidimensional}

A caracterização do proteoma do FI de laranjeiras amostradas na Fazenda Cambuhy pode ser vista na Figura 12. Como os proteomas do FI de folhas de árvores diferentes são semelhantes, considerando folhas nãoinfectadas com Xf, infectadas sem sintomas de CVC e infectadas com sintomas de CVC, elas foram misturadas para análise por eletroforese bidimensional.

Os resultados da eletroforese bidimensional das proteínas do $\mathrm{FI}$ de folhas não-infectadas com Xf, infectadas sem sintomas e infectadas com sintomas de CVC, por eletroforese bidimensional podem ser vistos nas Figuras 13, 14 e 15 respectivamente. A maioria das proteínas apresenta pl entre 4 e 7 e massa molecular (MM) aparente entre 6 e 42kDa. A predominância de proteínas ácidas, no $\mathrm{FI}$ de citros, vem confirmar relatos na literatura sobre a presença dessas proteínas na região apoplástica (Biles \& Abeles, 1991). Através da análise dos géis, utilizando o programa ImageMaster, foram detectados 99 proteínas circuladas de azul no mapa de referência do FI de folhas não-infectadas com Xf (Figura16). A análise comparativa dos proteomas do $\mathrm{Fl}$ de folhas não-infectadas com Xf e de folhas infectadas sem sintomas de CVC, pode ser vista na Figura 17. Foram detectadas 24 proteínas (azul) únicas do FI de folhas infectadas sem sintomas de CVC; 15 proteínas (vermelho) tiveram seu acúmulo aumentado no $\mathrm{FI}$ de folhas não-infectadas, e 3 proteínas (verde) tiveram seu acúmulo suprimido, em relação ao FI de folhas nãoinfectadas. O restante das proteínas (circulados de azul) apresentaram o mesmo nível de acúmulo nas duas situações. Das proteínas com acúmulo induzido no $\mathrm{FI}$ de folhas infectadas com Xf e sem sintoma de CVC, 5 proteínas 


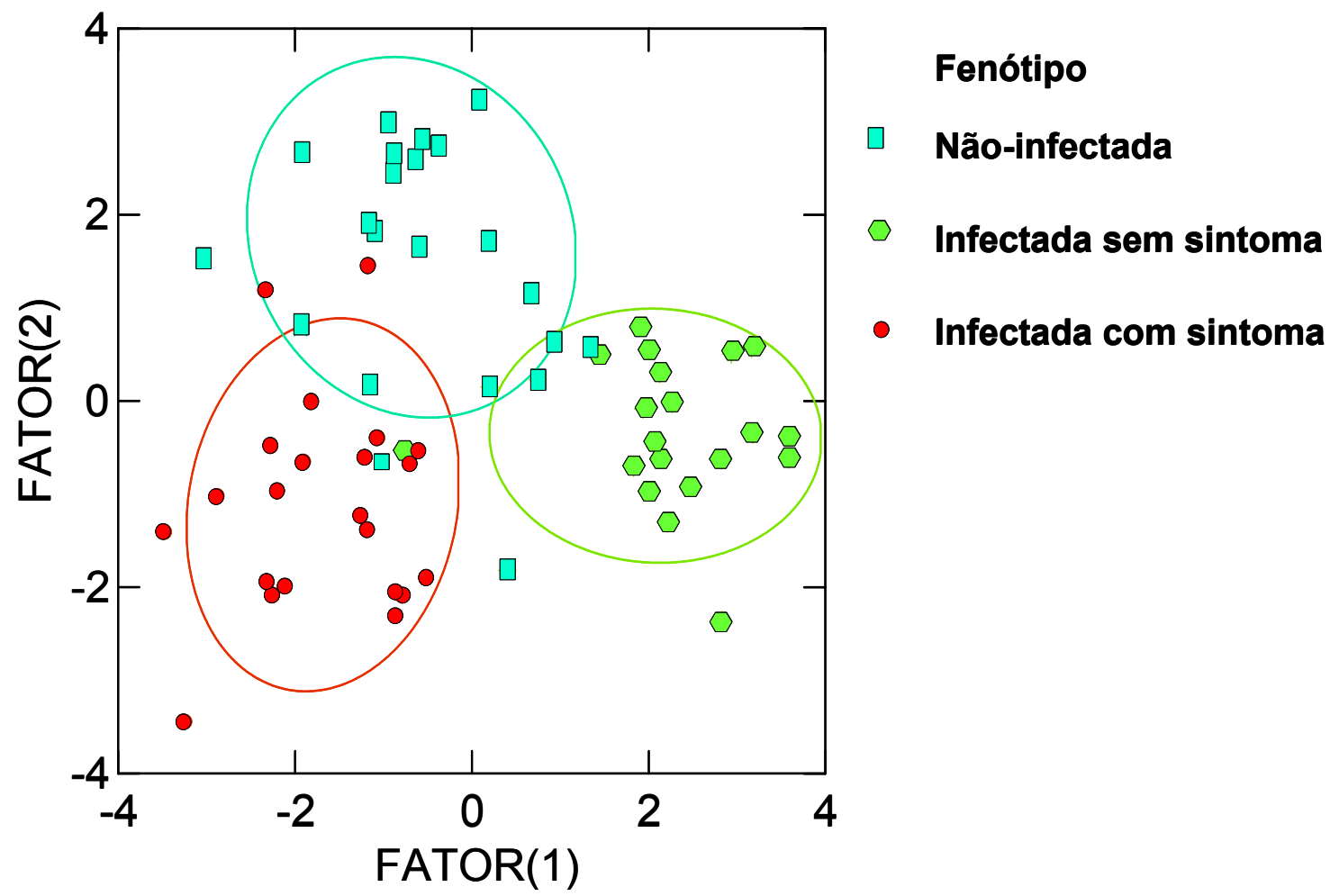

Figura 11 - A análise discriminante amostras do $\mathrm{FI}$ de folhas de laranjeiras com diferentes fenótipos, com base na ocorrência relativa de proteínas detectadas através de eletroforese em gel de poliacrilamida (15\%) desnaturante e coloração com prata. As elipses representam o intervalo de confidência $(p<0,01)$. Fator(1) e Fator(2) são as variáveis canônicas. 


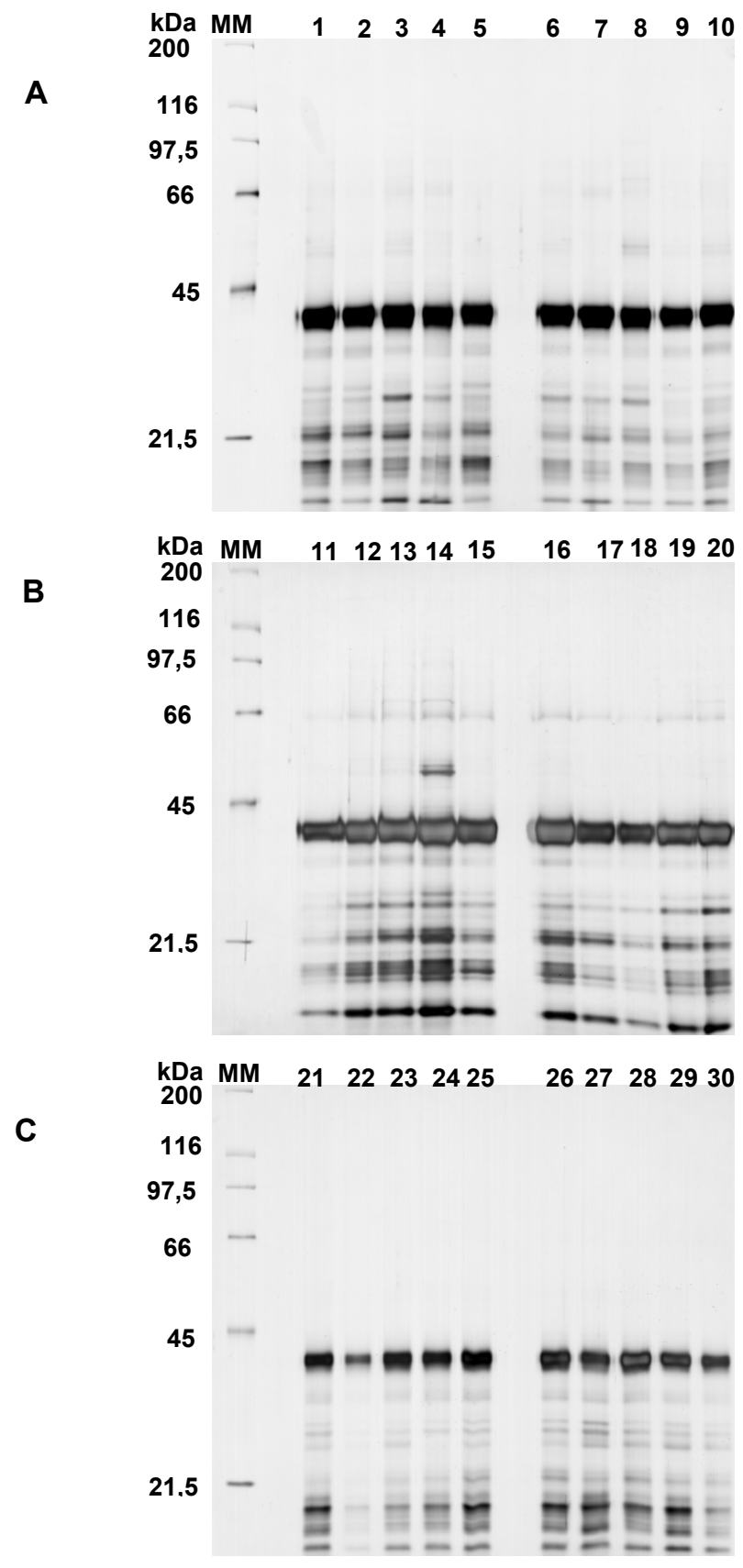

Figura 12 - Perfil de proteínas totais do FI de folhas de laranjeira em géis de poliacrilamida $(12,5 \%)$ desnaturantes. Quantidades iguais de proteínas foram utilizadas $(4 \mu \mathrm{g})$. A. 1-10 plantas não-infectadas com Xf da borbulheira-fazenda Cambuhy, Matão. B. 11-20 plantas infectadas sem sintomas de CVC, do pomar da fazenda Cambuhy, Matão. C. 21-30: plantas infectadas com Xf e com sintomas, de CVC do pomar da Cambuhy, Matão. 


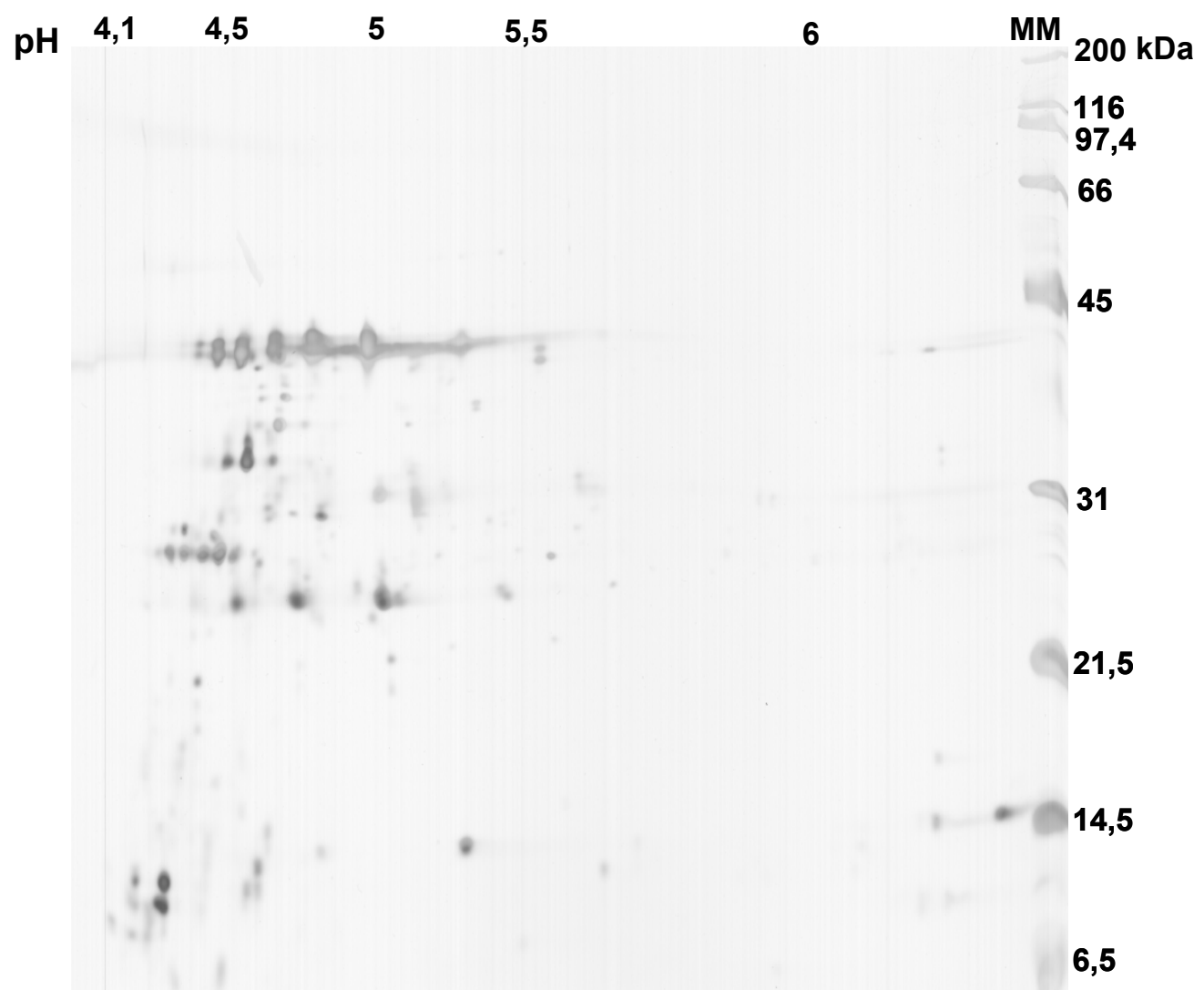

Figura 13 - Separação de proteínas do FI de laranjeira não-infectadas com Xylella fastidiosa por eletroforese bidimensional. Foram utilizados $40 \mu \mathrm{g}$. A focalização isoelétrica foi feita em gradiente não-linear de $\mathrm{pH}$ variando de 3 a10. MM, padrão de massa molecular. 


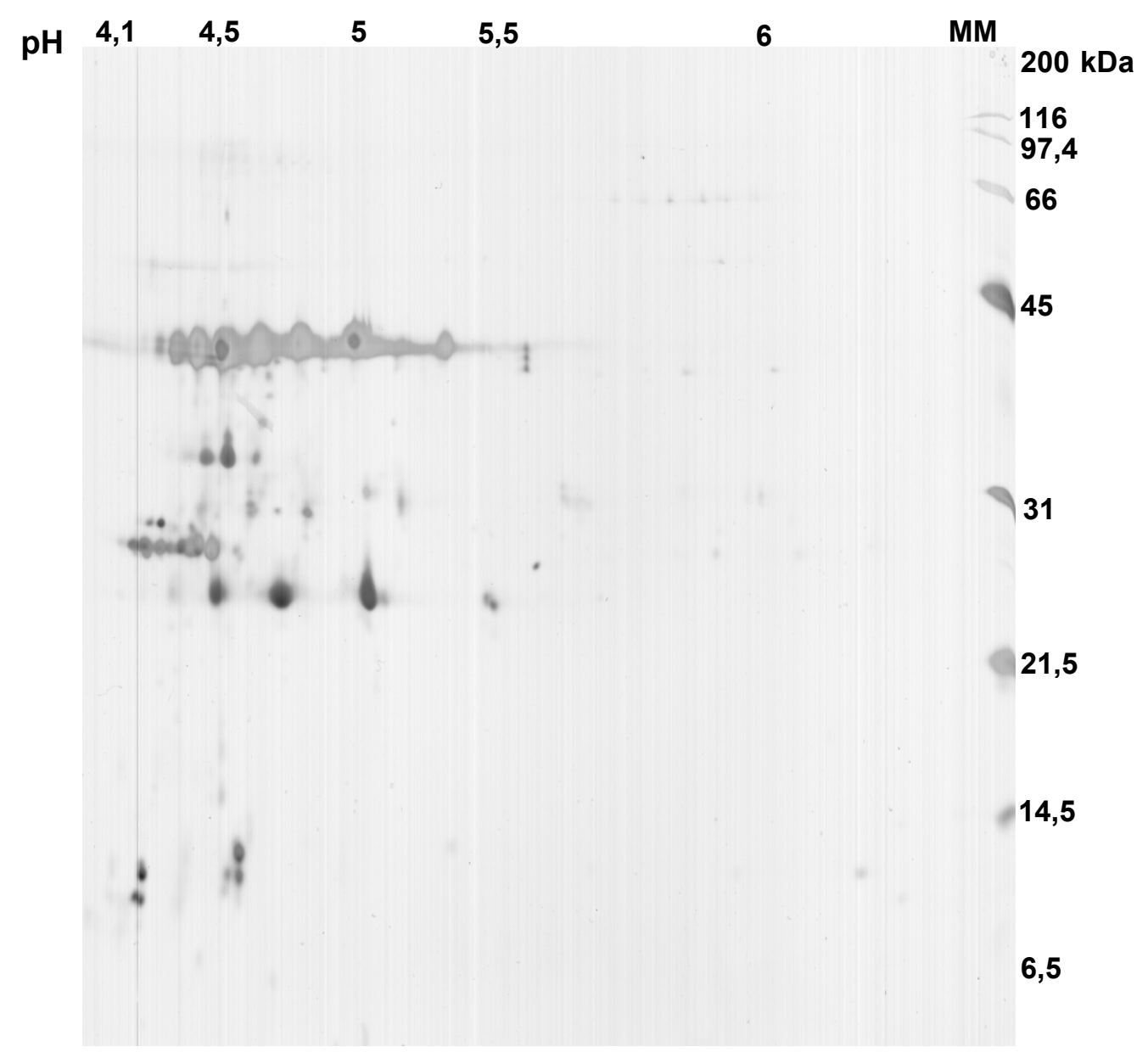

Figura 14 - Separação de proteínas do FI de laranjeira infectadas Xylella fastidiosa sem sintomas de CVC por eletroforese bidimensional. Foram utilizados $40 \mu \mathrm{g}$. A focalização isoelétrica foi feita em gradiente não-linear de $\mathrm{pH}$ variando de 3 a10. MM, padrão de massa molecular. 


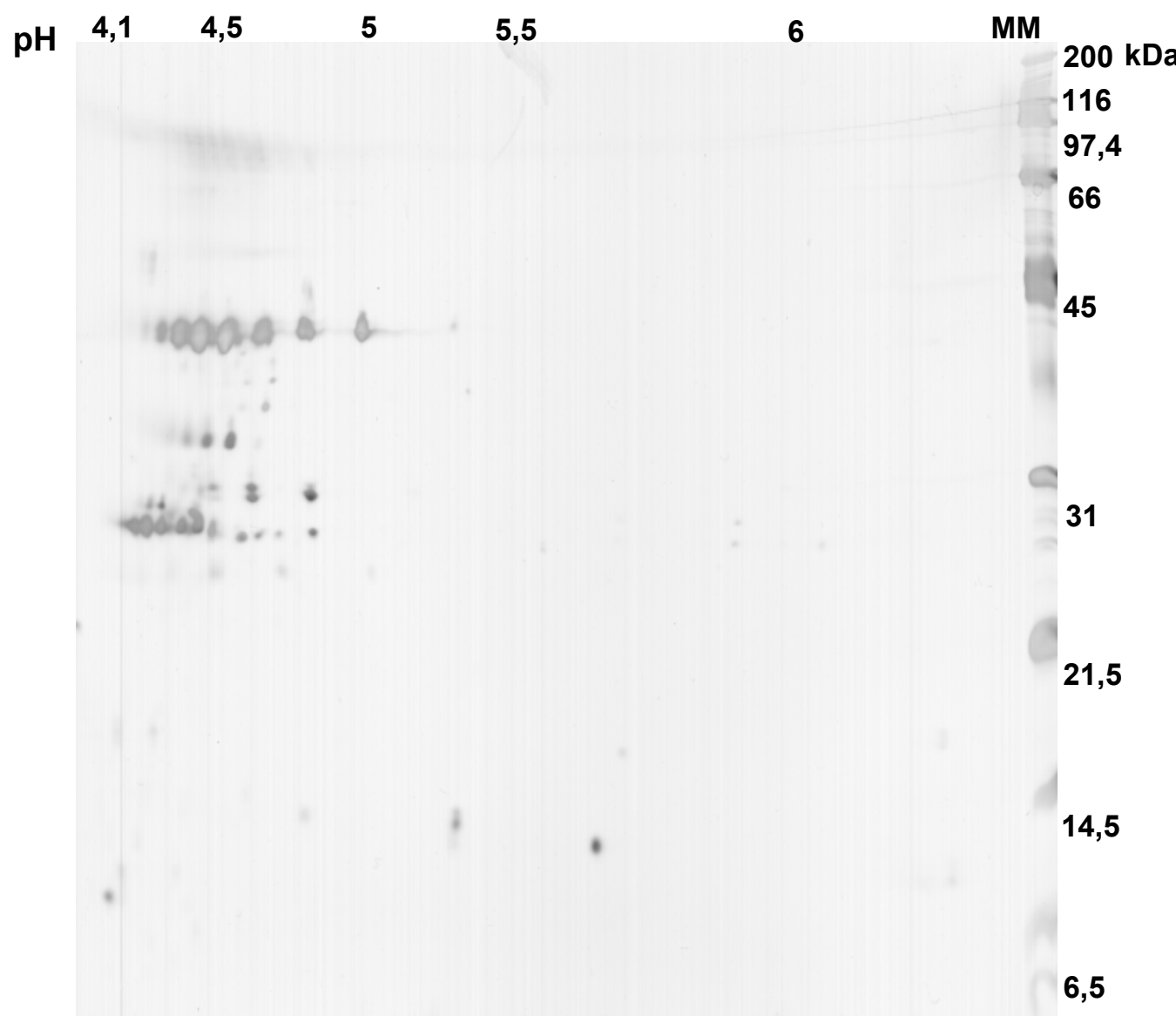

Figura 15 - Separação de proteínas do FI de laranjeiras infectadas Xylella fastidiosa com sintomas de CVC por eletroforese bidimensional. Foram utilizados $40 \mu \mathrm{g}$. A focalização isoelétrica foi feita em gradiente não-linear de $\mathrm{pH}$ variando de 3 a 10. MM, padrão de massa molecular. 


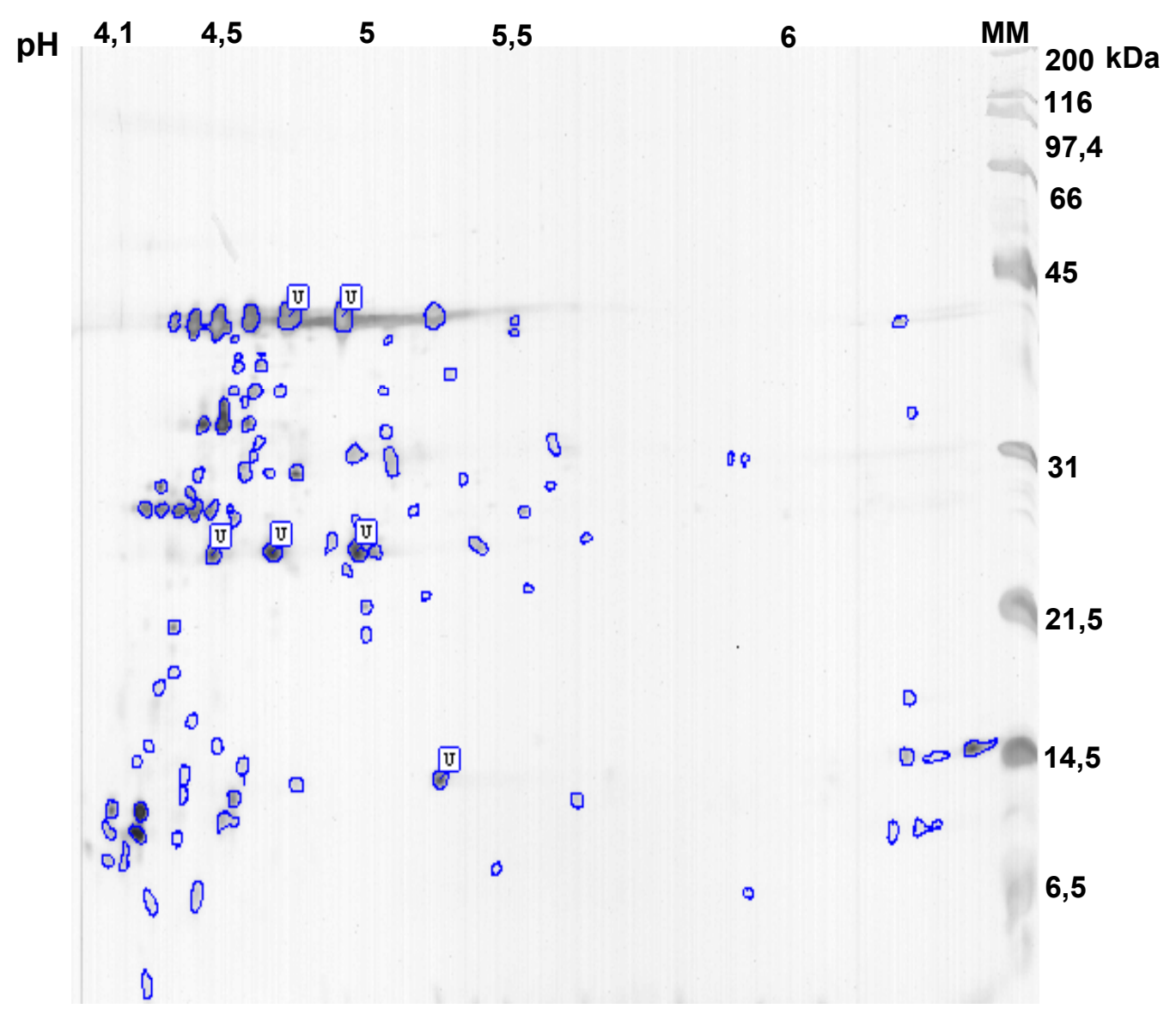

Figura 16 - Mapa de referência das proteínas do FI de folhas não-infectadas por Xylella fastidiosa. MM, marcador de massa molecular. U seeds usada para o alinhamento dos géis. 


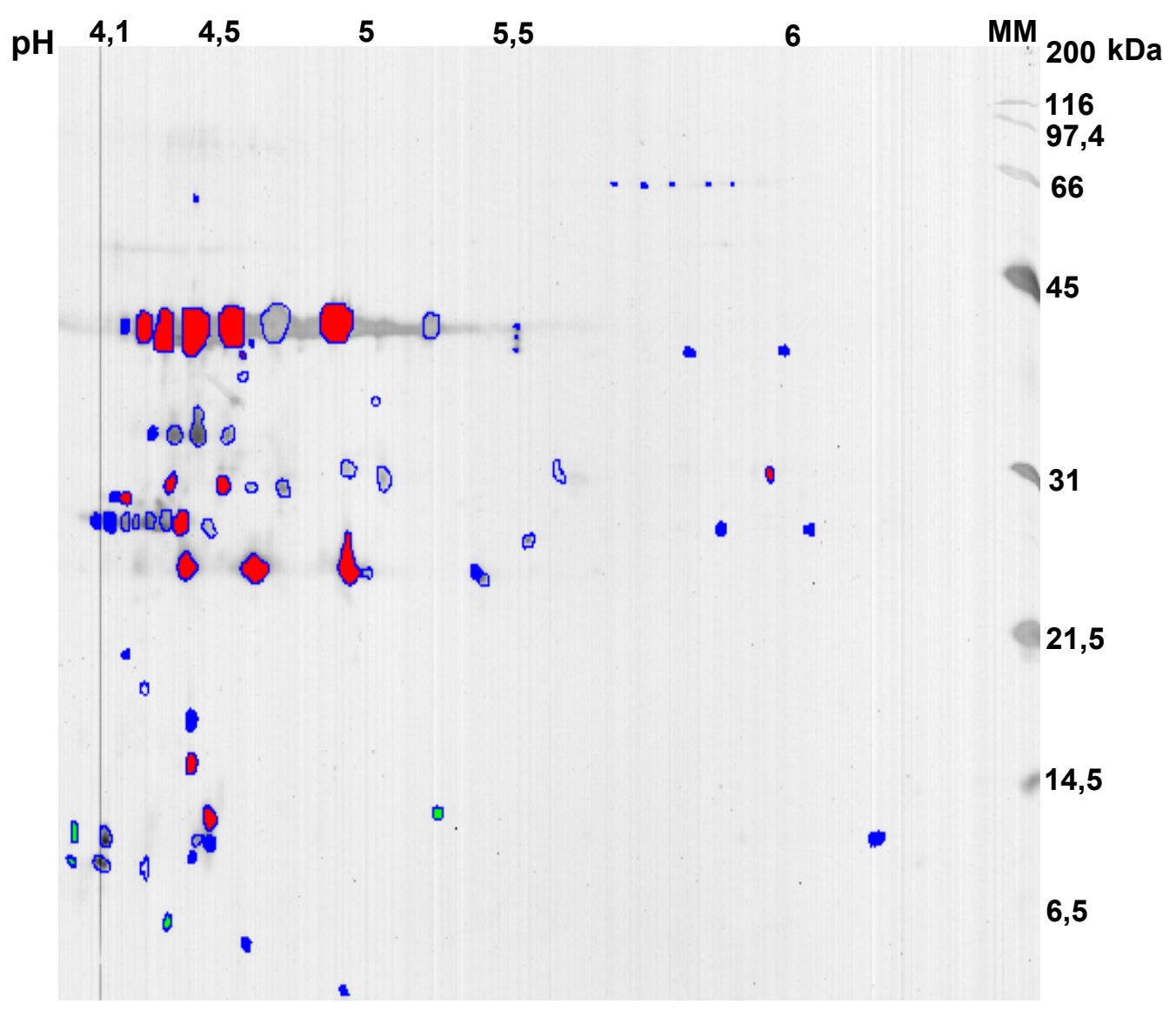

Figura 17 - Mapa comparativo de proteínas do FI de folhas de laranjeira nãoinfectadas com Xf e infectadas sem sintomas de CVC. O mapa de referência utilizado para a comparação foi o do FI de folhas nãoinfectadas. As manchas que aparecem em vermelho, indicam proteínas com acúmulo induzida em relação ao $\mathrm{FI}$ de folhas não-infectada. As manchas que aparecem em verde indicam proteínas com acúmulo suprimido em relação ao $\mathrm{Fl}$ de folhas não-infectada. As manchas que aparecem em azul representam proteínas presentes somente no FI de folhas infectadas sem sintomas. As manchas circulados de azul representam proteínas que apresentaram o mesmo nível de acúmulo no FI de folhas não-infectadas e infectadas sem sintomas. 
a mesma massa molecular aparente de $41 \mathrm{kDa}$ e pl de 4,2 e 5 . O acúmulo dessas proteínas teve uma variação de aumento entre 89 a 123\% em relação ao FI de folhas não-infectadas. Três outras proteínas que apresentam massa molecular aparente de $24 \mathrm{kDa}$ e o pl de 4,7 e 5,2 tiveram uma variação de aumento de 56 a 91,3\% em relação ao $\mathrm{FI}$ de folhas não-infectadas. A Figura 18 compara os proteomas do $\mathrm{Fl}$ de folhas não-infectadas com $\mathrm{Xf} e$ folhas infectadas com sintomas de CVC. Dezenove proteínas presentes somente no FI de folhas infectadas com sintomas foram detectados; 2 proteínas (vermelho) tiveram o seu acúmulo no $\mathrm{FI}$ de folhas infectadas com sintomas aumentado em relação ao FI de folhas não-infectadas; 8 proteínas (verde) tiveram seu acúmulo suprimido no $\mathrm{FI}$ de folhas infectadas com sintomas, em relação ao $\mathrm{FI}$ de folhas não-infectadas. O restante das proteínas (circulados de azul) apresentaram o mesmo nível de acúmulo nas duas situações. O acúmulo da proteína de $41 \mathrm{kDa}$, pl 4,5 foi de aproximadamente $30 \%$ maior no $\mathrm{Fl}$ de folhas infectadas com sintomas do que no $\mathrm{FI}$ de folhas não-infectadas. O acúmulo da proteína $41 \mathrm{kDa}$ e pl 4,8 foi de aproximadamente $63 \%$ menor do que no $\mathrm{Fl}$ de folhas não infectadas. O acúmulo das proteínas que apresentam massa molecular aparente de $24 \mathrm{kDa}$ e pl de 4,6 a 5,3 apresentaram uma variação de diminuição 70 a $93 \%$ em relação ao $\mathrm{FI}$ de folhas não-infectadas. Na Figura 19, foram comparadas os proteomas do FI de folhas infectadas sem sintomas (Figura 14) e infectadas com sintomas. O gel de referência utilizado nesta comparação foi do proteoma do $\mathrm{FI}$ de folhas sem sintomas. Vinte e sete proteínas (azul) são únicas do FI de folhas infectadas com sintomas; 4 proteínas (vermelho) tiveram o seu acúmulo aumentado em relação infectadas sem sintoma; 7 proteínas (verde) tiveram seu acúmulo suprimido em relação ao $\mathrm{FI}$ de folhas infectadas sem sintomas. O restante das proteínas (circulados de azul) não apresentaram alterações em relação ao $\mathrm{FI}$ de folhas infectadas sem sintomas. O acúmulo da proteína de $41 \mathrm{kDa}$, pl 4,8 foi de aproximadamente $50 \%$ maior no $\mathrm{Fl}$ de folhas infectadas com sintomas do que no $\mathrm{Fl}$ de folhas infectadas sem sintomas enquanto que a proteína de $41 \mathrm{kDa}$ e pl 5,2 foi de $65 \%$ menor no $\mathrm{FI}$ de folhas 


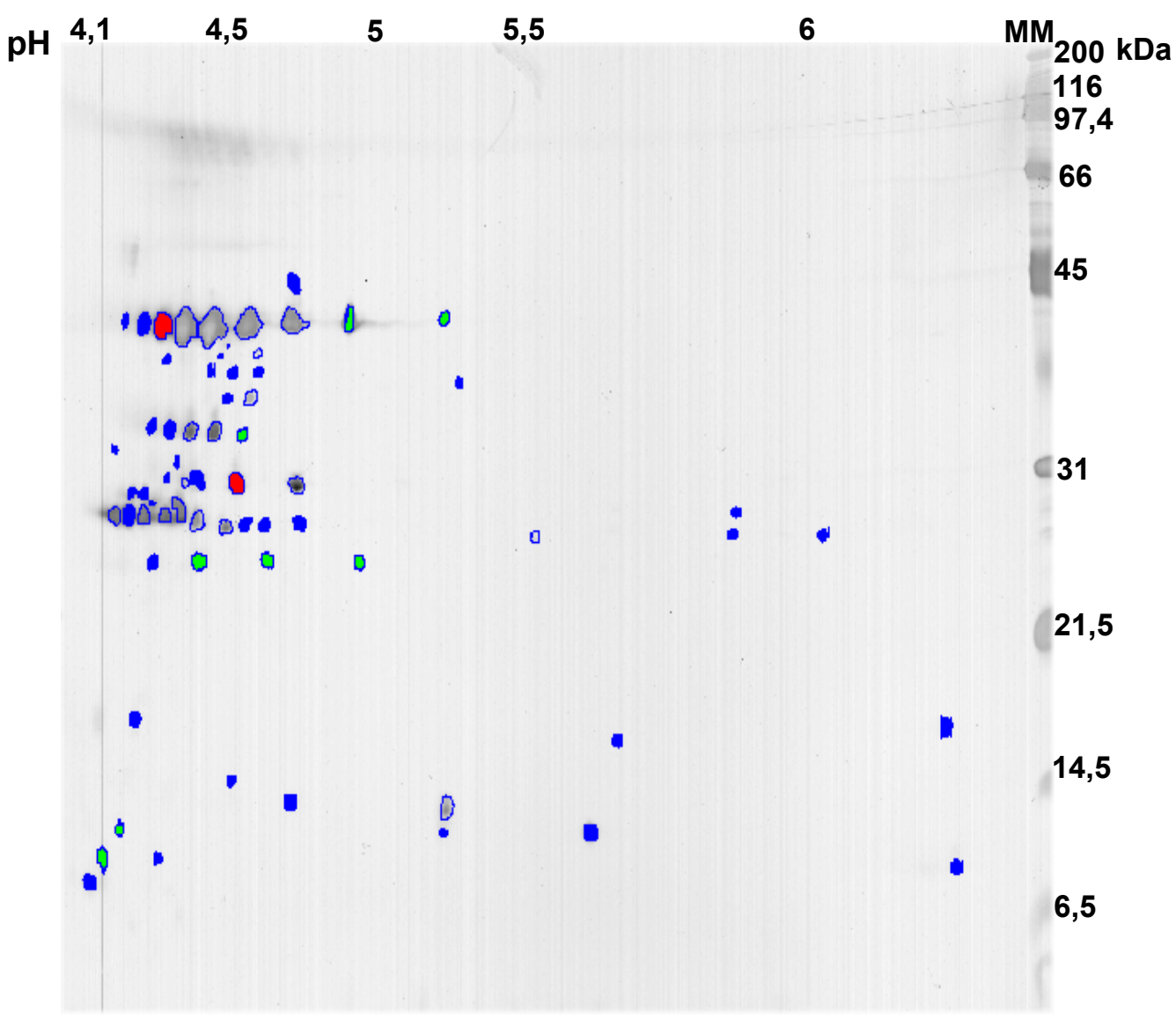

Figura 18 - Mapa comparativo de proteínas do FI de folhas de laranjeira nãoinfectadas com Xf e infectadas com sintomas de CVC. O mapa de referência utilizado para a comparação foi o do FI de folhas nãoinfectadas. As manchas que aparecem em vermelho, indicam proteínas com acúmulo induzida em relação ao $\mathrm{FI}$ de folhas não-infectada. As manchas que aparecem em verde indicam proteínas com acúmulo suprimido em relação ao $\mathrm{Fl}$ de folhas não-infectada. As manchas que aparecem em azul representam proteínas presentes somente no $\mathrm{Fl}$ de folhas infectadas sem sintomas. As manchas circulados de azul representam proteínas que apresentaram o mesmo nível de acúmulo no FI de folhas não-infectadas e infectadas sem sintomas. 


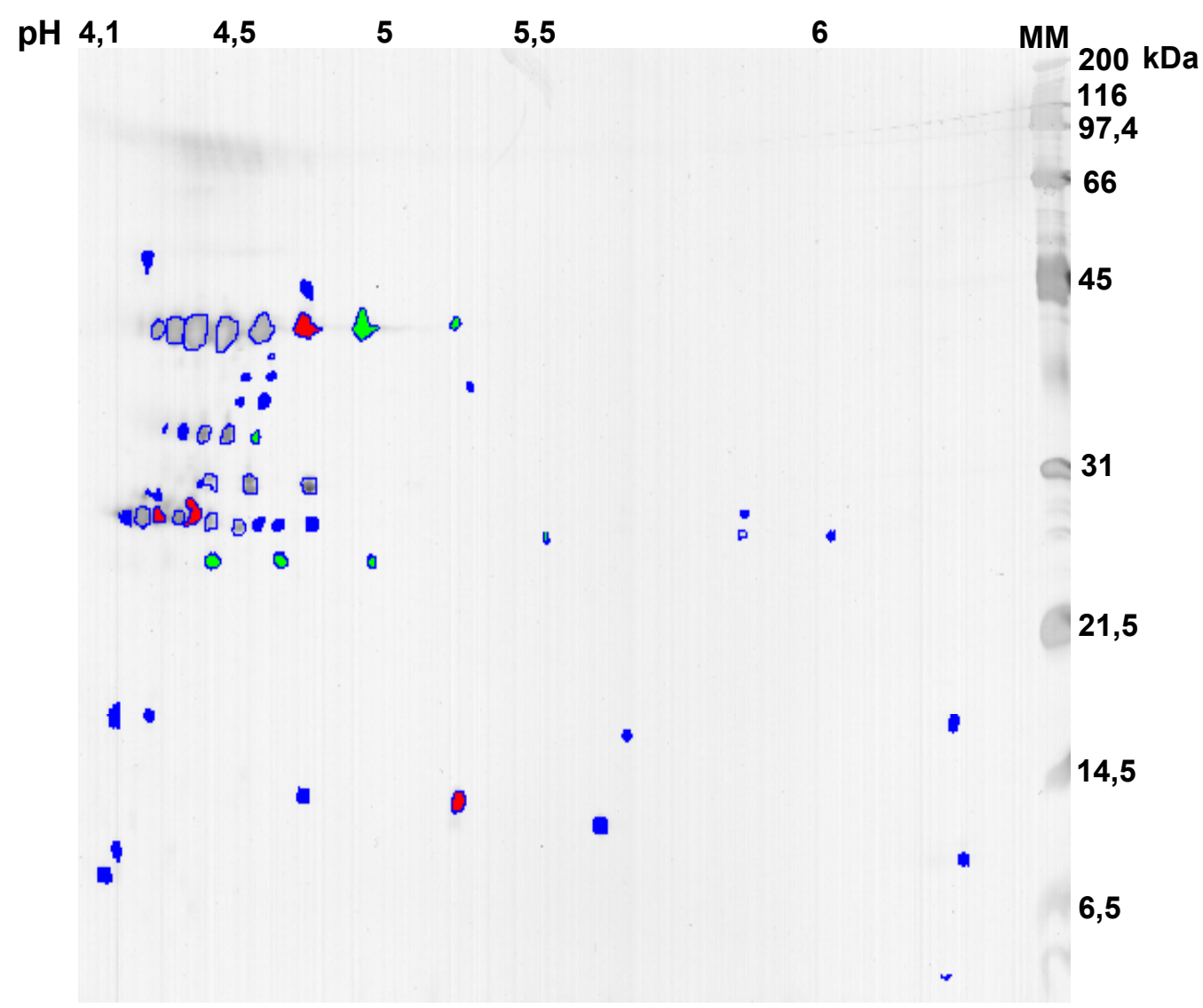

Figura 19 - Mapa comparativo de proteínas do FI de folhas de laranjeiras infectadas com Xf e sem sintomas de CVC e infectadas com sintomas de CVC. O mapa de referência utilizado para a comparação foi o do $\mathrm{FI}$ de folhas infectadas sem sintomas. As manchas que aparecem em vermelho, indicam proteínas com acúmulo induzida em relação ao $\mathrm{FI}$ de folhas infectadas sem sintomas deCVC. As manchas que aparecem em verde indicam proteínas com acúmulo suprimido em relação ao $\mathrm{FI}$ de folhas infectadas sem sintomas de CVC. As manchas que aparecem em azul representam proteínas presentes somente no $\mathrm{FI}$ de folhas infectadas com sintomas. As manchas circulados de azul representam proteínas que apresentaram o mesmo nível de acúmulo no $\mathrm{FI}$ de folhas infectadas sem sintomas e infectadas com sintomas de CVC. 
infectadas com sintomas do que no $\mathrm{Fl}$ de folhas infectadas sem sintomas. $\mathrm{O}$ acúmulo das proteínas que apresentam massa molecular aparente de $24 \mathrm{kDa}$ e pl de 4,6 a 5,2 apresentam uma variação diminuição de 90 a $98 \%$ em relação ao FI de folhas infectadas sem sintomas. Os dados apresentados mostram que proteínas provavelmente vegetais, apresentam níveis de acúmulo alterados no FI de folhas de laranjeiras infectadas com Xf com ou sem sintoma de CVC, e sugere que essas proteínas poderiam estar associadas com o desenvolvimento dos sintomas de CVC e folhas. Da mesma forma proteínas únicas de folhas do FI de folhas infectadas com sintomas poderia estar associada ao desenvolvimento dos mesmos. Essas proteínas deverão ser melhor caracterizadas, e sua regulação diferencial comparadas, utilizando outras técnicas analíticas. Um dos problemas da análise comparativa de proteoma por eletroforese bidimensional é a normalizar a quantidade de proteínas a ser utilizada na focalização isoelétrica, de forma que os géis em análise contenham quantidades iguais de proteínas. Como a concentração de proteínas no FI é baixa, há necessidade de se utilizar concentrá-las. Neste trabalho, utilizou-se a concentração de proteínas através da precipitação com solução acidificada de acetona. Esse procedimento pode resultar em perdas de certas proteínas e/ou precipitação desigual nas diferentes amostras. Ou seja, pequenas diferenças resultantes de artefatos gerados pela metodologia empregada podem existir entre diferentes proteomas. Muitas das proteínas únicas de um determinado proteoma ocorrem em baixas concentrações e são difíceis de serem visualizados nos géis. Uma alternativa para se resolver esse problema, seria utilizar maiores quantidade de proteínas na eletroforese bidimensional. Entretanto esse procedimento leva à obtenção de mapas distorcidos, em função das proteínas que ocorre em alta concentração, dificultando a individualização das mesmas e a análise do gel.

O padrão de migração da eletroforese bidimensional nas três situações amostradas mostrou a presença de seis ou mais proteínas de aproximadamente $41 \mathrm{kDa}$ (Figura 4), extremamente abundantes no FI de folhas 
de laranjeiras. A massa molecular aparente $1 \mathrm{a}, 1 \mathrm{~b}$ e $1 \mathrm{c}$ das isoformas é de $41,1 \mathrm{kDa}$ e seus pl aproximados são de 5,16, 4,97 e 4,83, respectivamente. As proteínas 1d, 1e e 1 f apresentam uma massa molecular aparente de 40,7kDa e seus pl aproximados são de 4,5, 4,6 e 4,57, respectivamente. As proteínas 1a e 1e tiveram suas extremidades $\mathrm{N}$-terminal seqüenciadas. $\mathrm{O}$ seqüenciamento gerou peptídeos idênticos, (ASQADIIPNNANYLIXIS), sugerindo que são proteínas isoformas de uma mesma família.

Para determinar que as proteínas $1 \mathrm{~b}, 1 \mathrm{c}, 1 \mathrm{~d}$ e $1 \mathrm{f}$ também fazem parte da mesma família, utilizou-se espectometria de massa (Figuras 20, 21 e 22). O espectro de massa dos peptídeos gerado pela digestão das proteínas $41 \mathrm{kDa}$ (1a-1f, Figura 3) com tripsina pode ser visto na Figura 20. A análise do espectro de massa de peptídeos gerado pela digestão tríptica das proteínass 1a-1f, individualizadas (Figura 21) indica que essas proteínas possuem a mesma seqüência de aminoácidos. No entanto, pequenas diferenças no espectro de massa dos peptídeos podem ser observados entre 1000 e 1100 (Figura 22). As diferenças no espectro de massa dos peptídeos e no pl observados sugere que essas isoformas sofrem modificações pós-tradução, como glicosilação, (Goldenberg \& Creighton, 1984). Em plantas superiores, muitas proteínas e enzimas são codificadas por famílias multigênicas e, em Arabidopsis, estima-se que $20 \%$ dos genes pertencem a membros da mesma família (Bevan et al., 1998). A existência de famílias de multigênicas pode, muitas vezes, refletir níveis adicionais de controle genético ou a existência de proteínas isoformas com função específicas (Mekhedov et al., 2000). Para obter informações sobre a identidade das isoformas da proteína de $41 \mathrm{kDa}$, as mesmas foram submetidas à digestão com tripsina e os peptídeos resultante separados por HPLC de fase reversa (Figura 4). Das frações obtidas, as de número 2, 4 e 5 tiveram suas seqüências $\mathrm{N}$-terminal determinadas pela degradação de Edman. As seqüência de aminoácidos obtida foram: fração 2: XNXGP; fração 4: DSYELVPASSTK; fração 5: VADTGSDLIXXQ. A porção $\mathrm{N}$-terminal das isoformas $41 \mathrm{kDa}$, bem como os peptídeos internos não mostraram homologia 


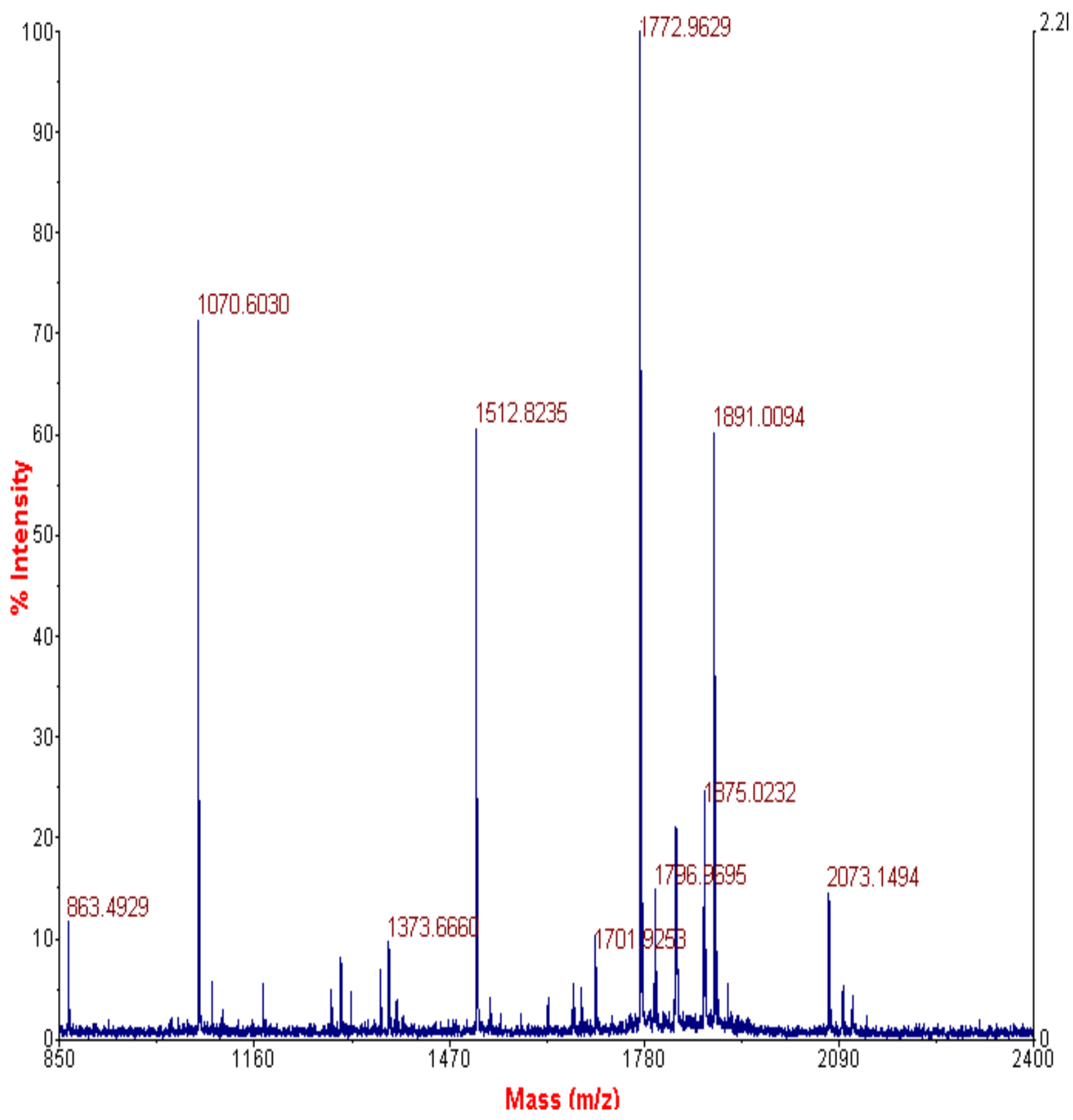

Figura 20 - Espectro de massa de peptídeos gerado pela digestão tríptica das proteínas de $41 \mathrm{kDa}$ e pl 4 a 5,5 . 

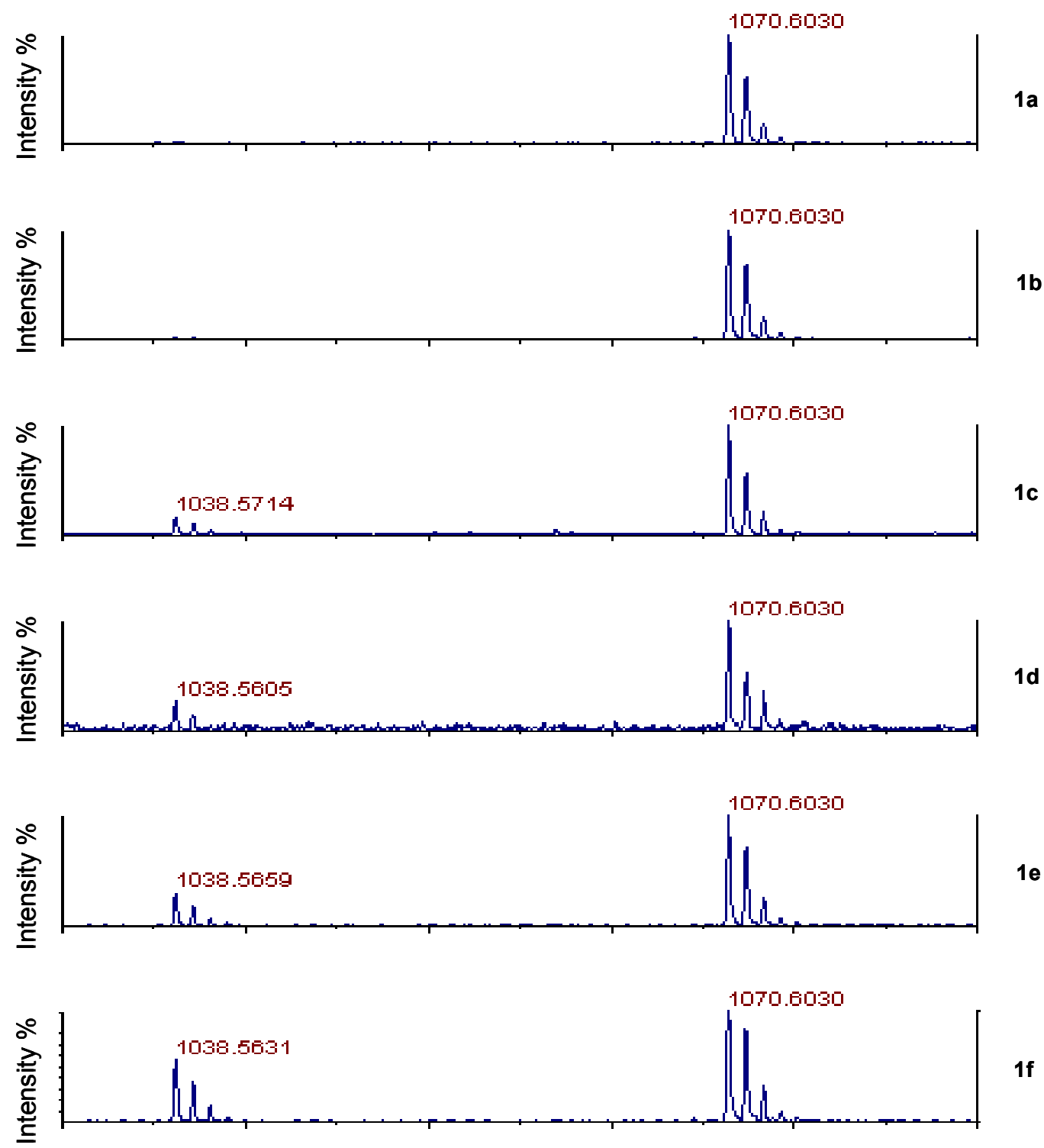

$1 f$

Figura 21 - Espectro de massa de peptídeos gerado pela digestão tríptica das proteínas de $41 \mathrm{kDa} .1 \mathrm{a}-\mathrm{f}$ representam as isoformas. 

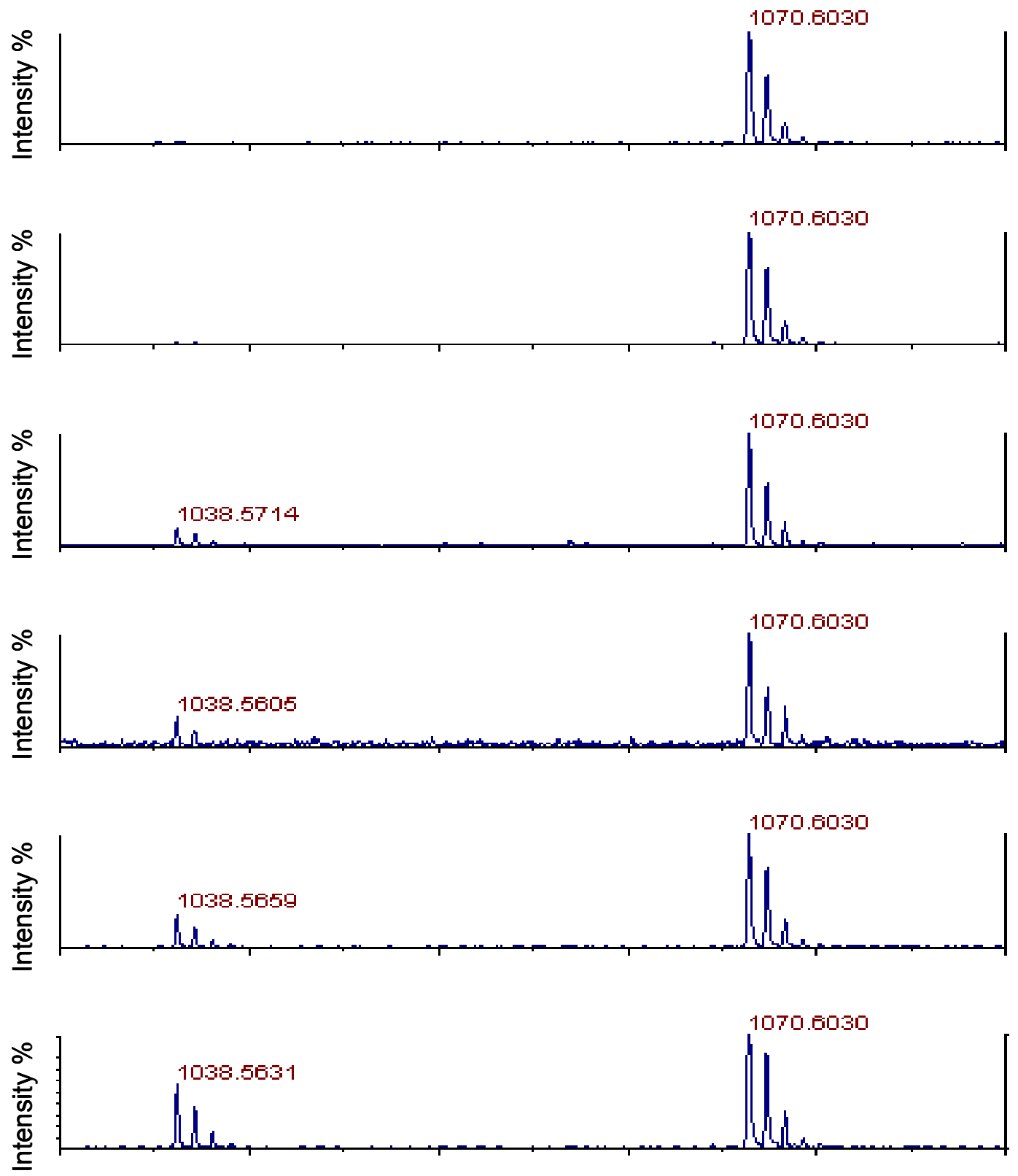

Figura 22 - Espectro de massa de peptídeos entre 1000 e 1100 (m/Z)das seis isoformas indicando pequenas diferenças. 1a-f representam as isoformas. 
significativa com proteínas/genes nos bancos de dados públicos e do SUCEST, sugerindo que pode se tratar de uma proteína específica de citros. No entanto, somente a seqüência completa das proteínas e/ou do gene(s) que codifica $(\mathrm{m})$ poderá mostrar que essas proteínas são únicas de citros. A proteína 3 (Figura 3) também foi submetida ao seqüenciamento $\mathrm{N}$-terminal, mas não foi possível determinar sua seqüência de aminoácidos, pois sua extremidade $\mathrm{N}$-terminal estava bloqueada. A proteína 4 (Figura 3) também foi submetido ao seqüenciamento $N$-terminal e apresentou a seguinte seqüência: FDITNNEP(D ou P)T. A seqüência obtida, não apresento homologia com proteínas/genes nos bancos de dados públicos.

Experimentos adicionais, como caracterização bioquímica dessas proteínas e clonagem do gene que as codificam serão necessários para estabelecer se elas têm ou quais são seus papéis no desenvolvimento e controle da CVC. 


\section{CONCLUSÕES}

Através dos resultados obtidos, nas condições em que o experimento foi realizado, conclui-se que:

a) O proteoma do FI de plantas de localidades diferentes são distintos, independente da presença de Xf e ou sintomas de CVC.

b) Independente do local onde as amostras foram coletadas, o proteoma do FI de folhas não-infectadas, infectadas sem sintomas e infectadas com sintomas são distintos.

c) Através da eletroforese bidimensional foi possível detectar proteínas com acúmulo diferencial no $\mathrm{FI}$ de folhas de laranjeiras infectadas com $\mathrm{Xf}$, com ou sem sintomas de CVC. As proteínas mais abundantes do $\mathrm{FI}$ de folhas de laranjeiras são de uma família de isoformas de mesma massa aparente de $41 \mathrm{kDa}$ e pl variando de 4,1 a 5,5 . Isoformas da proteína de $41 \mathrm{kDa}$ apresentaram acúmulo diferencial no $\mathrm{FI}$ de folhas de laranjeira infectadas com $\mathrm{Xf}$, e pode estar associado ao desenvolvimento de sintomas de CVC.

d) As seqüências $\mathrm{N}$-terminal das proteínas com acúmulo diferencial selecionadas não apresentaram homologia significativa com proteínas/genes em bancos de dados públicos. Estudos sobre a caracterização bioquímica dessas proteínas serão necessários para determinar o papel dessas proteínas no desenvolvimento e controle da CVC. 


\section{REFERÊNCIAS BIBLIOGRÁFICAS}

AGRIOS, G.N. Plant pathology. 4.ed. San Diego: Academic Press, 1997. 635p.

ALTSCHUL S.F.; MADDEN, T.L.; SCHAFFER, A.A; ZHANG, J.; ZHANG, Z, MILLER, W.; LIPMAN, D.J. Gapped BLAST and PSI-BLAST: a new generation of protein database search programs. Nucleic Acids Research, v.25, n.17, p.3389-3402, 1997.

BARRET, A.J.; SALVERSEN, G. Proteinase inhibitors. Amsterdam: Elsevier, 1986.

BERGMEYER, J.; GRASSL, M. Methods of enzymatic analysis. Weinheim: Verlag Chemie, 1983. v.3, p.15-21.

BEVAN, M.; BANCROFT, I.; BENT, E. et al. Analysis of $1.9 \mathrm{Mb}$ of contiguous sequence from chromosome 4 of Arabidopsis thaliana. Nature, v.391, n.6666, p.485-488, 1998.

BILES, C.L.; ABELES, F.B. Xylem sap protein. Plant Physiology, v.96, n.2 p.597-601, 1991.

BLUM, H.; BIER, H.; GROSS, H. J. Improved silver staining of plant proteins, RNA and DNA in polyacrilamide gels. Electrophoresis, v.8, n.2, p.93-95, 1987. 
BRADFORD, M.M. A rapid and sensitive method for the quantitation of microgram quantities of protein utilizing the principle of protein-dye binding. Analytical Biochemistry, v.72, n.1-2, p.248-254, 1976.

CARR, J.; KLESSIG, D.F. The pathogenesis-related proteins of plants. In: SETLOW, J.K. Genetic engineering-principles and methods. New York: Plenum Press, 1990. v.2, p.65-109.

CHANG, C.J.; SCHAAD, N.W. Electrophoretic protein profiles of total cell envelopes of xylem-limited plant pathogenic rickettsia-like bacteria (RLB). Phytopathology, v.72, n.7, p.935-36, 1982.

CHEN, J.; CHANG, C.J.; JARRET, R.L. Plasmids from Xylella fastidiosa strains. Canadian Journal of Microbiology, v.38, n.9, p.993-995, 1992a.

CHEN, J.; CHANG, C.J.; JARRET, R.L.; GAWEL, N. Genetic variation among Xylella fastidiosa strains. Phytopathology, v.82, n.9, p.973-977, 1992b.

DAVIS, M.J.; PURCELL, A.H.; THOMSOM, S.V. Isolation media for the Pierce's disease bacterium. Phytopathology, v.70, n.5, p.425-29, 1980.

DAVIS, M.J.; RAJU, B.C.; BRLANSKY, R.F.; LEE, L.W.; TIMMER, R.C.; NORRIS, R.C.; McCOY, R.E. Periwinkle wilt bacterium: axenic culture, pathogenicity and relationship to other Gram negative, xylem-inhabiting bacteria. Phytopathology, v.73, n.11, p.1510-15, 1983.

DAVIS, M.J.; RAJU, B.C.; BRLANSKY, R.H.; LEE, R.F.; TIMMER, L.W. Periwinkle wilt bacterium: axenic culture, pathogenicity, and relationships to 
other Gram -negative, xylem-inhabiting bacteria. Phytopathology, v.73, n.11, p.1510-15, 1983.

DAVIS, M.J.; WHITCOMB, R.F.; GILLASPIE, A.G. Jr. Fastidious bacteria of plant vascular tissue and invertebrates (including so-called rickettsia-like bacteria). In: STARR, M.P.; STOLP, H.O.; TRUPER, H.G.; BALOWS, A.; SCHLEGEL, H.G. The Prokaryotes: a handbook on habitats, isolation, and identification of Bacteria. New York: Springer-Verlag, 1980. p.21722188

DAVIS, M.J.; PURCELL, A.H.; THOMSON, S.V. Pierce's disease of grapevines: isolation of the causal bacterium. Science, v.199, n.4324, p.75-77, 1978.

DE NEGRI, J.D. Clorose Variegada do Citrus: nova anomalia afetando pomares em São Paulo e Minas Gerais. Campinas: CATI, 1990. 6p. (Comunicado Técnico, 38)

DIXON, R.A.; HARRISON, M.J.; LAMB, C.J. Early events in the activation of plant defense responses. Annual Review of Phytopathology, v.32, n.1, p.479-501, 1994.

FRENCH, W.J.; STASSI, D.L. Response of phony-infected peach trees with gibberellic acid. Horticultural Science, v.13, n.2, p.158-159, 1978.

FRENCH, W.J.; KITAGIMA, E.W. Occurrence of plum leaf scald in Brazil and Paraguay. Plant Disease reporter, v.62, n.12, p.1035-1038, 1978.

FUNDO DE DEFESA DA AGRICULTURA(FUNDECITUS). Clorose variegada dos citros (CVC).http://www.fundecitrus.com.br. (03/08/2001) 
GOLDENBERG, D.P \& CREIGHTON, T.E. Gel-Electrophoresis in studies of protein conformation and folding. Analytical Biochemistry,v.138, n.1, p.118, 1984.

GÖRG, A.; POSTEL, W.; WESER, J.; GÜNTHER, S.; STRAHLER, J.R.; HANASH, S.M.; SOMERLOT, L. Elimination of point streaking on silverstained two-dimensional gels by addition of iodoacetamide to the equilibration buffer. Electrophoresis, v.8, n.2, p.122-124, 1987.

GRANIER, F. Extraction of plant proteins for two-dimensional electrophoresis. Eletrophoresis, v.9, n.11, p.712-718, 1988.

GRIGNON, C.; SENTENAC, H. pH and ionic conditions in apoplast. Annual Review Plant Physiology Plant Molecular Biology, v.42, n.1, p.103-128, 1991.

GUERREIRO, N.; WEINMAN, J. J.; NATERA, S.; MORRIS, A.C.; REDMOND, J.W.; DJORDJEVIC M.A.; ROLFE, B.G. Separation and caracterization of Rhizobium and Trifolium protein using proteome analysis to study global changes in gene expression. In: STACEY, G.; MULLIN, B.; GRESSHOFF, P.M. Biology of Plant-Microbe Interations, St. Paul, International Society for Molecular Plant-Microbe Interations.1996. p.359-362.

GUERREIRO, N.; REDMOND, J.W.; ROLFE, B.G.; DJORDJEVIC. New Rhizobium leguminosarum flavonoid-induced proteins revealed by proteome analysis of differentially displayed proteins. Molecular PlantMicrobe Interactions, v.10, n.4, p.506-516, 1997. 
GUTTEMBERG, M.; HAMPP, R. Ectomycorrhizins: symbiosis-specific or artifactual polypeptides from ectomycorrhizas. Planta, v.188, n.1, p.129136, 1992.

HAMMOND-KOSACK, K.E. Preparation and analysis of intercellular fluid. In: GURR, S.J.; MCPHERSON, M. J.; BOWLES, D.J. Molecular Plant Pathology. Oxford: Oxford University, 1992. v.2, p.15-21.

HAYWARD, A.C.; MARIANO, R.L.R. Mecanismos de virulência e patogenicidade de procariotos em plantas. Revisão Anual de Patologia de Plantas, v.5, n.1, p.199-234, 1997.

HOPKINS, D. L. Production of diagnostic symptoms of blight in citrus inoculated with Xylella fastidiosa. Plant Disease, v.72, n.5, p.434-35, 1988.

HOPKINS, D.L.; MORTENSEN, J.A. Suppression of Pierce's disease symptoms by tetracycline antibiotics. Plant Disease, v.55, n.7, p.610-612, 1971.

HOPKINS, D.L. Variability of virulence in grapevine among isolates of Pierce's disease bacterium. Phytopathology, v.74, n.11, p.1395-1398, 1984.

HOPKINS, D.L. Xylella fastidiosa: A xylem-limited bacterial pathogen of plants. Annual Review of Phytopathology, v.27, p.271-290, 1989.

ISAAC, S. Fungal-plant interactions. London: Chapman \& Hall, 1992. p.418.

JENÖ, P.; MINI, T.; MOES, S.; HINTERMANN. E.; HORST, M. Intermal sequences from proteins digested in polyacrylamide Gels. Analytical Biochemistry,v.224, n.1, p.75-82, 1995. 
KAMPER, S.M.; FRENCH, W.J.; DeKLOET, S.R. Genetic relationship of some fastidious xylem-limited bacteria. International Journal of Systematic of Bacteriology, v.35, n.2, p.185-188, 1985.

KASSANIS, B.; GIANINAZZI, S.; WHITE, R.F. A possible explanation of the resistance of virus-infected tobacco plants to second infection. Journal of Genetics of Virology,v.23, n.1, p.11-16,1994.

KELLER B. Structural cell wall proteins. Plant Physiology, v.101, n.4, p.11271130, 1993.

LAMBAIS, M. R. Fisiologia molecular de micorrizas arbusculares. Piracicaba, 1998. 95p. Tese (Livre-Docência) - Escola Superior de Agricultura "Luiz de Queiroz", Universidade de São Paulo.

LAEMMLI, U.K. Cleavage of structural proteins during the assembly of the head of bacteriophage T4. Nature, v.227, p.680-685, 1970.

LEE, R.F.; RAJU, B.C.; NYLAND, G.; GOHEEN, A. C. Phytotoxin(s) produced in culture by the Pierce's disease bacterium. Phytopathology, v.71, n.7, p.886-888, 1982.

LEE, R.F.; BERRETA, M.J.G.; DERRICK, K. Clorose variegada dos citros: uma nova e destrutiva doença dos citros no Brasil. Laranja, v.12, n.2, p.345356, 1991a.

LEE, R.F.; DERRICK, K.S.; BERRETA, M.J.G.; CHAGAS, C.M.; ROSSETTI, V. Citrus variegated chorosis: a new destructive disease of citrus in Brazil. Citrus Industry, v.12, n.1, p.10-15, 1991b. 
LEITE, R.M.V.B.; STALL, R.E.; HOPKINS, D.L.; MINSAVAGE, G.V. Caracterização de estirpes de Xylella fastidiosa através da análise de DNA genômico e plasmídeo. Summa Phytopathologica, v.19, p.46, 1993, Suplemento.

LEITE, R.M.V.B.; LEITE JR, R.P.; CEREZINE, P.C. Hospedeiros alternativos para Xylella fastidiosa entre plantas invasoras de pomares de amexeira com escaldadura da folha. Fitopatologia Brasileira, v.22, n.1, p.54-57, 1997.

LOUWS, F.J.; FULBRIGHT, D.W.; STEPHENS, C.T.; de BRUIJN, F.J. Differentiation of genomic structure by REP-PCR fingerprinting to rapidly classify Xanthomonas campestris pv. vesicatoria. Phytopathology, v.85, n.5, p.528-536, 1995.

MACHADO, M.A.; SILVÉRIO, J.L.; BAPTISTA, C.R.; CRISTOFANI, M.; SOBRINHO, J.T. Avaliação de transmissão e seleção de variedades à Clorose Variegada dos Citros (CVC). Laranja, v.13, n.2, p.515-531, 1992.

MARSHAK, D.R.; KADONAGA, J.T.; BURGESS, R.R. et al. Strategies for protein purification and characterization: a laboratory manual. 1.ed. New York: Cold Spring Harbor Laboratory Press, 1996.1v

MATSUDAIRA, P. Sequence from picomole quantities of proteins electroblotted onto PVDF membranes. Journal Biology Chemistry, v.262, n.21, p.10035-10038, 1987. 
MEHTA A.; ROSATO YB. Differentially expressed proteins in the interaction of Xanthomonas axonopodis pv. citri with leaf extract of the host plant. Proteomics,v.1, n.9, p.1111-1118, 2001.

MEKHEDOV, S.; MARTÍNEZ, O.I.; OHRROGGE, J. Toward a functional catalog of the plant genome. A survey of genes for lipid biosynthesis. Plant Physiology, v.122, n.1, p.389-401, 2000.

MIZUBUTI, E.S.G.; MATSUOKA, K.; ARIZZI, P. Associação de bactérias do tipo Xylella em laranjeiras com sintomas de clorose variegada na região da Mata de Minas Gerais. Fitopatologia Brasileira, v.19, n.12, p.241-242, 1994.

MUKHERJEE, A.; CUI, Y.; LIU, Y.; DUMENYO, C.K.; CHATTERJEE, A.K. Global regulation in Erwinia species by Erwinia caratovora rsmA, a homologue of Escherichia coli csrA: repression of secondary metabolites, pathogenicity and hypersensitive reaction. Microbiology UK, v.142, n.1, p.427-434, 1996.

NATERA, S.H.A.; GUERREIRO, N.; DJORDJEVIC, M.A. Proteome analysis of differentially displayed proteins as a tool for the investigation of symbiosis. Molecular Plant-Microbe Interactions, v.13, n.9, p.995-1009, 2000.

NIEDERMAN T.; GENETE Y.; BRUYĖRE T.; et al. Pathogenesis-related PR-1 proteins are antifungal-Isolation and characterization of 3-14 kilodalton proteins of tomato and of basic PR-1 of Tobacco with inhibitory activity against. Plant Physiology, v.108, n.1, p.17-27, 1995.

O' FARRELL, P.H. High-resolution two dimensional electrophoresis of proteins. The Journal of Biological Chemistry, v.250, n.10, p.4007-4021, 1975. 
PASCHOLATI, S.F.; LEITE, B. Hospedeiro: mecanismos de resistência. In: BERGAMIN FILHO, A.; KIMATI, H.; AMORIM, L. (Ed). Manual de fitopatologia: princípios e conceitos. 3.ed. São Paulo: Editora Agronômica Ceres, 1995. v.1, cap.22, p.417-453.

POOLER, M.R.; HARTUNG, J.S. Specific PCR detection and identification of Xylella fastidiosa strains causing citrus variegated chlorosis. Current Microbiology, v.31, n.6, p.377-381, 1995.

PURCELL, A. H. Homopterum transmission of xylem-limited bacteria. In: Advances in Disease Vector Research. New York: Springer-Velag. v.6, 1990.

QUEIROZ-VOLTAN, R.B.; PARADELA FILHO, O. Caracterização de estruturas anatômicas de citros infectados com Xylella fastidiosa: Laranja, v.20, n.1, p.55-76, 1999.

ROSSETI, V.; DE NEGRI, D. Clorose Variegada dos citros: Revisão. Laranja, v.11, n.1, p.1-14, 1990.

ROSENFELD, J.; CAPDEVIELLE, J.; GUILLEMT, C. J.; FERRARA, P. In-gel digestion of proteins for internal sequence analysis after one or twodimensional gel electrophoresis. Analytical Biochemistry, v.203, n.1, p.173-179, 1992.

SALUNKHE, D. K.; SHARMA, R.P.; Introduction to phytoalexins. In: SALUNKHE, D. K.; SHARMA, R.P. Mycotoxins and Phytoalexins. BocaRaton: CRC Press, 1991. cap.19. 
SIMPSON, A.J.G.; REINACH, F.C.; ARRUDA, P. et al. The genome sequence of the plant pathogen Xylella fastidiosa. Nature, v.406, n.6792, p.151-157, 2000.

STINTZI, A.; HEITZ, T.; PRASAD, V. et al. Plant "pathogenesis-related" proteins and their role in defense against pathogens. Biochemie, v.75, n.8, p.687706, 1993.

TAHARA, S.T. Expressão diferencial de proteínas e mRNAs na interação de Xanthomonas axonopodis pv. passiflorae com hospedeiro compatível. Campinas, 2000. 99p.Tese (Doutorado) - Universidade de Campinas.

TRAVENSOLO, R.F.; LEITE, JR.; R.P. Hospedeiro alternativos de Xylella fastidiosa entre plantas invasoras de pomares de citros com clorose variegada. Fitopatologia brasileira, v.21, p.336, 1996. Suplemento. IApresentado ao 29. Congresso Brasileiro de Fitopatologia, Ihéus, 1996

TUBELIS, A. Difusão da clorose em pomares de São Paulo e Minas Gerais (Levantamento realizado pela Fundecitrus). Informativo Coopercitrus, v.72, n.1, p.24-30, 1992a.

TUBELIS, A. Difusão temporal da Clorose Variegada dos Citros em pomares comerciais de laranjas doce no estado de São Paulo e Minas Gerais, Brasil. / Apresentado ao Encontro sobre Amarelinho dos Citros (ou CVC), Piracicaba, 1992b. p.21-23

TUBELIS, A.; BARROS, J.C.; LEITE, R.M.V.B. Difusão da Clorose Variegada dos Citros em pomares comerciais de laranja doce no Brasil. Laranja, v.14, n.1, p.239-254, 1993. 
VAN LOON, L.C. \& VAN KAMMEN, A. Polyacrylamide disc electrophoresis of soluble leaf proteins from Nicotiana tabacum var. 'Samsum'and 'Samsum NN'.Il. Changes in protein constitution after infection with tobacco mosaic virus. Virology, v.30, n.1, p.199-211,1970.

VIERA, B.A.H. Revisão da Espécie Xylella fastidiosa (1999).<http://orbita.starmedia.com/ bervieira/revxylella.pdf>. (12/12/2000)

WELLS, J.M.; RAJU, B.C.; NYLAND, G.; LOWE, S.K. Medium for isolation and growth of bacteria associated with plum leaf scald and phony peach diseases. Applied and Environmental Microbiology, v.42, n.2, p.357363, 1981.

WELLS, J.M.; RAJU, B.C.; HUNG, H-Y.; WEISBURG, W.G.; MANDELCO PAUL, L.; BRENNER, D.J. Xylella fastidiosa gen. Nov., sp. Nov: Gramnegative, xylem-limited, fastidious plant bacteria related to Xanthomonas spp. International Journal of Systematic Bacteriology, v.37, n.2, p.136143, 1987.

WHEELER, C.H.; BERRY, S.L.; WILKINS, M.R. et al. Characterization of proteins from two-dimensional electrophoresis gels by matrix assisted laser desorption ionization mass spectrometry and amino acid compositional analysis. Electrophoresis, v.17, n.3, p.580-587, 1996.

WILKINS, M.R.; PASQUALI, C.; APPEL, R.D et al. From proteins to proteome: large scale protein identification by two-dimensional electrophoresis and aminoacid analysis. Biotechnology, v.14, n.1, p.61, 1996. 